741

1 $R 8 R_{3}$

UC-NRLF

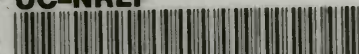

c 2962 401 


\section{EXCHANGE}
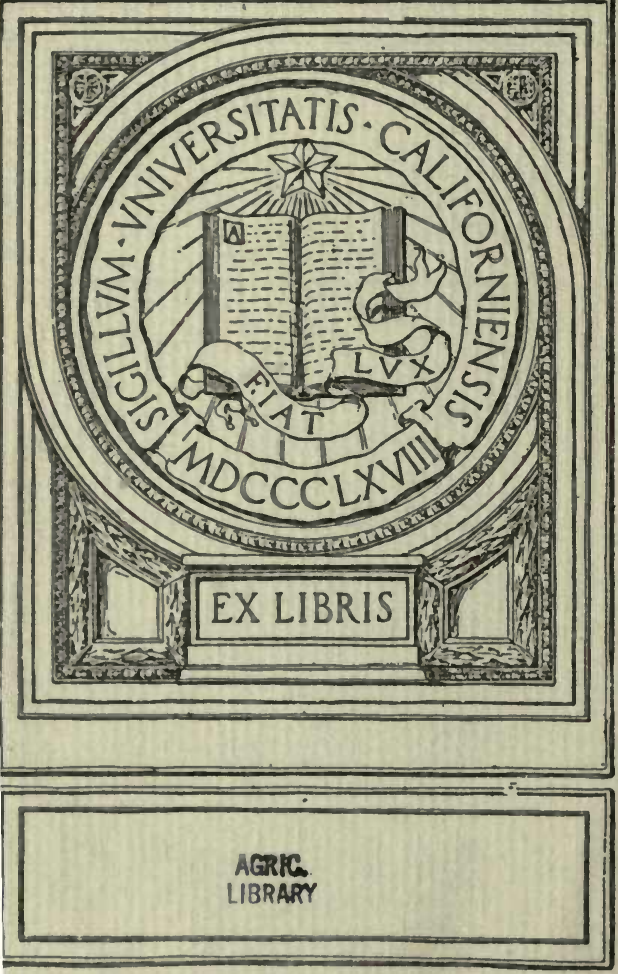


\title{
Vegetative Vigor of the Host as a Factor Influencing Susceptibility and Resistance to Certain Rust Diseases of the Higher Plants
}

\author{
BY \\ MORRIS ABEL RAINES
}

A Dissertation Submitted in Partial Fulfillment of the Requirements for the Degree of Doctor of PhiLosophy, in the Faculty of Pure Science, Columbia University. 



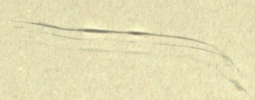





\title{
Vegetative Vigor of the Host as a Factor Influencing Susceptibility and Resistance to Certain Rust Diseases of the Higher Plants
}

\author{
BY \\ MORRIS ABEL RAINES
}

A Dissertation Submitted in Partial Fulfillment of the Requirements for tile Degree of Doctor of Philosophy, in the Faculty of Pure Science, Columbia University. 



\section{VEGETATIVE VIGOR OF THE HOST AS A FACTOR INFLU- ENCING SUSCEPTIBILITY AND RESISTANCE TO CERTAIN RUST DISEASES OF THE HIGHER PLANTS}

M. A. RAINES

(Received for publication July 13, 1921)

\section{INTRODUCTION}

Studies on the cereal rusts were made covering various phases of the phenomena of rust epidemiology, including the effects of season, age of the host plant, etc., on its susceptibility and on the virulence of the disease; effects of varying dosage in securing inoculation; effects of the general nutritional condition of the host, etc. In carrying out these studies I have had the opportunity to convince myself of the frequently observed fact that health and vigor of the host favor father than hinder its inoculation by a rust and the further development of the diseased condition. This observation has frequently been made and more or less casually reported in the literature on the rusts and other fungous diseases of plants. The significance of such observations in relation to general theories of immunity and resistance to disease has, however, nowhere been adequately recognized, and I have thought it worth while to bring together the available evidence bearing on this point.

It is a commonplace of pathological theory that the health and vigor of an organism and its susceptibility to disease are antithetic variables, that as one increases or is increased the other diminishes or is diminished correspondingly. Adami (1910, ${ }^{1}$ I : 409), summarizing the subject of predisposition to disease, lists the causes of acquired susceptibility as (I) social and environmental conditions; (2) injury; (3) malnutrition; (4) previous attack of the same disease or other infectious disease; and (5) exhaustion; all of them factors diminishing the vitality of the host. Zinnser (1914, p. 59), discussing the broader principles of infection and resistance, states:

A person suffering from functional impairment of any kind is more likely to permit the invasion of a pathogenic microörganism than is a perfectly healthy well-nourished individual of the same species.

Kolmer (I917, p. ror) says, similarly:

Acquired susceptibility . . may be due to various factors, most of which lead to a state of reduced vitality, normal physiologic processes being impaired to a greater or less degree.

${ }^{1}$ The list of literature cited will be found at the conclusion of the second paper of this series. 
Among plant pathologists, Jones (1905, p. 23) writes:

Disease resistance and vegetative vigor are closely associated, although the factors involved are not necessarily identical. . . . So far as the evidence goes it seems to suggest that high vegetative vigor enables the plant to ward off in some degree the fungus attack.

In direct contrast with this view it must be noted that workers in the field of the rust diseases of higher plants have on several occasions been prompted to generalize to directly the opposite effect-that they found host vigor and susceptibility to disease not antithetic, and not independent, but parallel variables. Arthur (1903, p. I3), in a presidential address before the Botanical Society of America, stated from his long experience with plant rusts that

So intimate is the association of parasite and host that as a rule the vigor of the parasite is directly proportional to the vigor of the host. Every culturist soon learns that to have success in his work he must employ strong, rapidly growing plants. Even if he succeeds in infecting weak plants, the fungus will rarely come to satisfactory fruitage.

Sheldon (1903, p. 74), summarizing his illuminating studies on the asparagus rust, concludes:

Lowered vitality does not favor infection.... Whatever affects the growth of the asparagus has a like effect on the rust.

Stakman, in his extensive studies on the cereal rusts, on several occasions expresses similar views. Thus (I9I4, p. 40) he concludes that

These experiments show that whatever is conducive to the vigorous development of the host is ordinarily conducive to the vigorous development of the parasite also.

And in another place (Stakman and Levine, 1919, pp. 75 and 76):

Deficiency of soil moisture and sunlight and other ecological factors affecting the host plant unfavorably appear to be equally unfavorable to the rust parasite. . . Adverse environmental conditions unfavorable to the host are also unfavorable for the parasite, affecting the virulence and spore size of the latter.

While the authors make their point incidentally and in no instance discuss their findings from the point of view of the general question of the relation between host vigor and susceptibility in infectious disease, it is evident that the question is suggested as to the possibly special and, from the point of view of the relation observed in the larger number of infectious diseases of plants and animals, peculiar relation between vegetative vigor of the host and susceptibility to infection in the rust diseases of the higher plants. The demonstration of such a peculiar relation would be of theoretical interest as limiting and qualifying the universality of the commonly accepted dictum that host vigor and virulence of disease are in inverse relation and would be of profound import in defining the practical problem of the prevention and control of the diseases concerned. 


\section{REVIEW OF LITERATURE}

Physiological studies on the rusts have been reported almost entirely from the point of view of a direct relation between the environmental factor concerned and the rust fungus, the essential intermediary between the two, the host, being kept more or less indistinctly in the background.-A marshaling of the available data on the physiology of the rusts from the point of view of the present study, the possible correlation between host vigor and virulence of the parasite, reveals a very general agreement in favor of the concept that in the rust diseases of the higher plants there is a tendency for the parasite to exhibit a higher incidence of infection and greater virulence on the host of greater vegetative vigor. Similar instances in other classes of plant diseases are cited in the general discussion.

\section{Host Nutrition: Nitrogen Nutrition and Mineral Nutrients}

\section{Field Studies}

Butler (1918, p. 73) describes the coffee leaf disease (Hemileia vastatrix B. \& Br.) as having first appeared on some of the best coffee in Ceylon, and states that it is, in the case of this disease, considered as established that fungous infection and growth occur better in strong leaves, rich in nutriment, than in those with less food supply.

The greater susceptibility to rust of wheat grown on highly fertile land has been noted repeatedly. Little (I883, p. 634) states that high manuring, especially with nitrogenous manures, predisposes wheat plants to rust. And Bolley (I889, p. I7) writes that

It is a matter of common note that soils rich in organic plant foods, such as low-lying loams, are quite liable to produce rusted crops; and in England, where great quantities of nitrogenous fertilizers are used, much has been said as to the liability of the crop to rust upon fields to which such manures have been applied. Such observations go to confirm the belief that soils excessively rich in nitrogen, either natural or applied, produce wheat easily attacked by rust.

Freeman and Johnson (I9I I, p. 69), in their general review of the cereal rust problem in the United States, state:

... It is now well established that where there is an excess of nitrogen in the soil, other things being equal, grains are more severely attacked by rust than crops on soil containing less nitrogen. . . . Where barnyard manures have been applied heavily the result is similar, and where grains are grown after a crop of clover, beans, or vetch, rusts may be expected. In fact it may be generally stated that where soils are rich in nitrogen, producing rank and succulent plant growth, rust attacks will, as a rule, be most severe on account of increased succulence of the plants, increased rankness of growth, delay in drying out after showers and dews, and slight delay in the ripening period. On the other hand phosphate of lime tends to shorten the ripening period and thus acts as a rust preventive to some extent. . . . In general, a rust attack is most virulent on a healthy plant.

Peacock (I9II) states that rust in wheat and oats is favored by pre- 
disposition due to a too vigorous growth in early life. Biffen (1912), in his studies on the inheritance in wheat of rust resistance to Puccinia glumarum, found that the rust is most virulent when a complete fertilizer is used, and that the virulence of the disease decreases with a decrease in the amount of fertilizer. Comparing the two principal types of asparagus soils in California, the sediment and the peat, Smith (1905, p. 56) notes that asparagus growing in the latter soil is considerably more damaged by the same amount of disease. He comments that on peat formations, composed almost entirely of vegetable matter and water, a very luxuriant, quickgrowing, tender, and succulent asparagus is produced.

Zavitz (I9I3) reports some very interesting observations on the relative susceptibility to rust of oats grown under conditions of varying thickness of seeding. The experiment was conducted through each of four years, using both large and small seed of heavy-stooling, medium-stooling, and light-stooling varieties of oats, and planting the seed of each variety in squares one, two, three, four, six, eight, and twelve inches apart. Table I is adapted from the data presented by Zavitz, and presents the average results of thirty-two tests made by planting oats at seven different distances apart. The results are the averages for four years.

TABLE I

\begin{tabular}{|c|c|c|c|c|c|c|c|}
\hline \multirow{2}{*}{$\begin{array}{l}\text { Inches } \\
\text { between } \\
\text { Plants }\end{array}$} & \multirow{2}{*}{$\begin{array}{c}\text { Number of } \\
\text { Heads per } \\
\text { Plant }\end{array}$} & \multirow{2}{*}{$\begin{array}{l}\text { Height } \\
\text { in } \\
\text { Inches }\end{array}$} & \multirow{2}{*}{$\begin{array}{l}\text { Per- } \\
\text { centage } \\
\text { Lodged }\end{array}$} & \multirow{2}{*}{$\begin{array}{c}\text { Days } \\
\text { to } \\
\text { Mature }\end{array}$} & \multicolumn{2}{|c|}{ Relative Yield per Plant } & \multirow{2}{*}{$\begin{array}{l}\text { Per- } \\
\text { centage } \\
\text { Rusted }\end{array}$} \\
\hline & & & & & Straw & Grain & \\
\hline I & 1.0 & 20.4 & 5.6 & $9 \mathrm{I}$ & 100 & 100 & 11.8 \\
\hline 2 & I.I & 27.8 & I 1.9 & 93 & $36 r$ & 457 & 15.0 \\
\hline 3 & 1.3 & 32.6 & 12.8 & 94 & 782 & 1,227 & 17.8 \\
\hline 4 & 2.0 & 33.1 & 29.9 & 95 & $\mathrm{I}, \mathrm{I} 79$ & 2,031 & 20.9 \\
\hline 6 & 4.2 & $35 \cdot 3$ & 35.8 & 97 & 2,823 & 4,402 & 25.4 \\
\hline 8 & 6.5 & 34.9 & 34.7 & 99 & 4,389 & 6,645 & 27.7 \\
\hline 12 & 11.2 & 34.9 & 30.1 & IOO & 8,475 & 10,320 & 33.2 \\
\hline
\end{tabular}

The greater amount of rust observed with the increased distance between plants is best correlated with the increased luxuriance of growth exhibited by these plants. The difference of a week in the time of maturing between the most closely spaced and the most liberally spaced oat plants is hardly sufficient to account for the difference in the amount of rust infection. Observations were made at frequent intervals through the summer, and a rust difference due only to difference in time of maturity would not have shown up in this fashion in the data. A more logical explanation is the increase in the amount of lodging which closely parallels the increase in percentage of rust from the one-inch spacing to the six-inch spacing. But from the six-inch spacing to the twelve-inch spacing the amount of lodging decreases appreciably while the percentage of rust increases further, indicating that the increase in the amount of rust is independent of lodging. There 
is the strong suggestion, therefore, in Zavitz's data that the increase noted in the amount of rust present on oat plants grown at progressively greater distances apart is correlated with the increased luxuriance of growth of the host plants.

\section{Water-Culture and Sand-Culture Studies.}

Ward (1902a) details two experiments on the susceptibility to rust infection of host plants which had been starved of essential nutrients. In the first experiment, 54 young seedlings of Bromus secalinus were used. The plants were grown in sand in 14 glass beakers, four to seven plants to a beaker, and watered with solutions of varying nutritive value. The plants in one beaker received only distilled water. The plants in another beaker received a cold-water extract of fresh horse dung, as a solution of high nutritive value. In a third beaker the plants received a full mineral nutritive solution (described as a "normal nutritive mineral solution containing nitrates, phosphates, and sulphates of potassium, calcium, and magnesium"). The remaining eleven beakers received an incomplete nutrient solution, the elements omitted being respectively $\mathrm{K} ; \mathrm{N} ; \mathrm{Mg}$; $\mathrm{Ca}$; $\mathrm{P} ; \mathrm{Fe} ; \mathrm{N}$ and $\mathrm{Fe} ; \mathrm{Mg}$ and $\mathrm{Fe} ; \mathrm{Ca}$ and $\mathrm{Fe} ; \mathrm{P}$ and $\mathrm{Fe}$. Inoculation was effected by applying uredospores of Puccinia dispersa to the leaves by means of a swab of cotton; at the time of inoculation the seedlings were 16 days old, counting from the time of sowing.

Ward records detailed observations on the stature, robustness, color, and number of leaves of the seedlings in each beaker; on the time of appearance, number, and size of the pustules developed on them, and on the relative number of spores produced. Comparing the twelve seedlings which showed the most vigorous growth ( 6 which received the extract of horse dung, 3 the full nutrient solution, and 3 the full nutrient solution minus $\mathrm{Fe}$, the plants averaging $20 \mathrm{~cm}$. in height) with the ten poorest plants ( 4 receiving distilled water, 3 the full nutrient solution minus $N$, and 3 the nutrient solution minus $\mathrm{N}$ and $\mathrm{Fe}$, the plants averaging II $\mathrm{cm}$. in height), the observations recorded by Ward indicate that in the plants suffering from malnutrition (I) the incubation period of the rust was lengthened by one and two days; (2) the rust pustules were much smaller and produced fewer spores. In other words, a starved host meant a starved parasite. There is also the suggestion in the data that the starved seedlings showed a lower incidence of infection; but the small number of variables worked with, together with the large irregularity in dosage inherent in the method of inoculation used, compel reserve in making this deduction.

A second experiment with 64 seedlings, duplicating the first, gave similar results. Regarding the spores produced on well nourished and on starved seedlings, Ward states that microscopic examination revealed no differences. Spores from starved seedlings could produce infection on other seedlings, similarly starved. 
In 1905, Ward reports experiments indicating that starving the host tissue after infection has taken place has an adverse effect on the growth of the fungous mycelium. He cut off infected leaves of cereals on the third day after artificial inoculation and floated them on water. Histological examinations of the leaves indicated that the rust fungus in the tissues continued to grow for a time, but soon showed signs of starvation.

Spinks (1913, p. 238) describes an experiment on the susceptibility to Puccinia glumarum of wheat plants grown in water cultures. He used six plants grown in each of three solutions: a standard nutrient solution (Detmer's); a nutrient solution containing four times the quantity of ammonium phosphate; and a nutrient solution containing four times the quantity of potassium chloride. The cultures were inoculated by applying uredospores to the leaves; they were then set outdoors, so that further spread of the rust occurred naturally. Spinks gives no data on the condition of the plants, and this can only be inferred from the mode of treatment they received. The data presented indicate that the plants growing in the nutrient solutions containing a four-fold concentration of nitrogen were more susceptible than those in the standard solution. Excess concentration of $\mathrm{KCl}$ gave an apparent slight depression of susceptibility.

Stakman (1914, p. 39) reports some experiments with Puccinia graminis tritici on wheat seedlings grown in water cultures. In an experiment in which nitrogen and phosphorus were omitted from the culture solutions, the check plants were more severely attacked than the experimental plants. Summarizing his results, Stakman says (p. 48):

It was found that in general the absence or presence in excessive amounts of various nutrient substances, such as nitrogen and phosphorus salts, did not directly affect the immunity or susceptibility of wheats. Conditions favoring a normal development of the host were conducive to a vigorous development of the rust. The action of fertilizers, either natural or artificial, is probably indirect.

\section{Soil-Culture Experiments}

Sheldon (1905, p. 226) remarks on the low susceptibility shown by poorly growing carnations to artificial infection with Puccinia Caryophylli:

The results show that the plants that were making a vigorous growth were more susceptible to artificial infection than those that were making little or no apparent growth. A few slowly growing plants were repeatedly inoculated without success until the plants were given extra care and stimulated so that they began to grow more vigorously. Some carnations, grown in small pots, were each inoculated five or six times at intervals of about twenty days without any of the inoculations being effective. These plants grew very slowly, were slender, and produced only one, or at most two, small blossoms.

In the same paper (p. 228) Sheldon reports an experiment on the length of the incubation period of the carnation rust in which he inoculated simultaneously 170 pinks growing in soils of varying nutritive values. The plants had been derived by taking sets of cuttings from the same stock plant, a 
green-leaved pink known to be very susceptible to carnation rust, and they were grown in five different soils ranging in composition from one that was principally sand to one containing chiefly organic matter. Sheldon's observations indicated that the growth of the host varied directly with the amount of organic matter, nitrogen, and silt in the different soils; and that with increased vigor and growth of the host the incubation period of the fungus decreased in length, from 21 days in the poorest plants to 16 days in the most vigorous individuals.

Miss Gibson (1904, p. 188) describes an experiment on the effects of nutritional treatment on the susceptibility of certain varieties of chrysanthemum to rust.

The young plants were then divided into four groups. $A$ were fed as if for exhibition; $B$ were grown normally; $C$ were starved by being grown in small pots; and $D$ were grown in a warm greenhouse.

The rust developed on all the plants, but a luxuriant state of growth of the host favored the greater development of the fungous mycelium.

Spinks (1913, p. 240) conducted an experiment on the susceptibility to rust of wheat plants grown in pots receiving different nutritive solutions. The data indicate somewhat higher susceptibility on the part of the plants richly fed with nitrogen. Stakman (1914, p. 16) finds that high fertilization of the soil increased the susceptibility to infection by Puccinia graminis tritici of resistant varieties of wheat, and so concludes that high fertilization is conducive to increased severity of rust attack on very resistant varieties as well as on susceptible forms.

Indicating that the effect of specific nutrient substances is indirect, secondary to their effect on the vigor of the host, is the observation by Stakman and Levine (1919, p. 72) that an application of sodium nitrate, excessive to the point of inhibiting the growth of the host, also inhibits the development of the rust and diminishes very perceptibly the size of the urediniospores. Ward (I902a) states that the size of the uredospores was not affected by starving the host. Stakman and Levine arrived at their observation that the size of the spores is affected by biometrical methods, which would cause to stand out distinctly size differences not apparent on gross examination. Ward does not give any spore measurements.

\section{Host Nutrition: Carbon Metabolism}

Intimate relation between the progress of a rust infection and the carbon metabolism of the host tissue has been demonstrated by Ward (1905), Fromme (1913), and Mains (1917). Sheldon (1903) studied the effect of light and temperature on rust development, and Stakman and his co-workers (1917, 1919) have studied quantitatively the effects of light on the cereal rusts.

Ward (I905, p. 40) refers to experiments on cereal rusts indicating that 
when, shortly after inoculation, the host is placed under conditions where it cannot manufacture carbohydrates, as by keeping it in the dark or in light from which the red-orange end of the spectrum is filtered off or in air deprived of carbon dioxide, the development of the rust is inhibited.

Fromme (I9I3, p. 5I6) found that placing oat plants recently inoculated with Puccinia coronifera in the dark for a period of several days increased the length of the incubation petiod of the rust by a corresponding interval. Fromme interprets the observation to indicate that the fungus is dependent for its nutrition on some intermediate product of photosynthesis.

Mains (I917, p. I9I) confirms Fromme's observation that the development of the crown rust of oats is retarded in the absence of light, and adds that if the infected plant is left in the dark too long (which would greatly impair the vitality and vigor of the host tissue) the rust is killed. Mains also independently repeated Ward's observation that growing the host plants in an atmosphere free from carbon dioxide inhibits the development of the rust. Similar experiments with Puccinia Sorghi on seedling plants of Zea Mays, however, failed to arrest the development of the rust. Further experiments showed that if the host leaf is supplied with carbohydrates, either from the reserve stores of the endosperm or by being floated under aseptic conditions on a sugar solution, then the rust develops successfully, even if, because of the absence of light or of carbon dioxide, the host tissue cannot manufacture its own carbohydrates. Mains is therefore prompted to qualify Fromme's inference that the rust is dependent upon intermediate products of photosynthesis into the statement that the rust is dependent upon transitory carbohydrates.

It does not necessarily follow from an observation that the development of the rust is inhibited upon a plant starved of an essential nutrientwhether carbon, or nitrogen, or potassium, etc.- that the rust fungus is dependent for its nutrition upon compounds of that substance. As long as the host plant is at all alive, or, even if it is dead, before disintegration of its substance has set in, it contains carbon, nitrogen, etc., compounds, and we cannot say that the rust could not develop because of the absence of such compounds. Such observations are best interpreted on the basis of the physiological condition of the host when it is starved of an essential nutrient substance. We can not say that a host plant starved of an essential nutrient is a host plant deficient in that particular class of substances; but we can say that a host plant starved of an essential nutrient is a host plant that is not assimilating, that is not growing, a plant in which anabolic processes are at a standstill and katabolic processes predominate. And we are justified in inferring from the observed behavior of rust fungi on host plants starved of essential nutrients that a plant which is not assimilating, which is not growing, in which anabolic processes are at a standstill and katabolic processes predominate. does not make a congenial host for the rust fungus. The suggestion that the rust is deperident for nutrition upon 
some particular class of substances within the host is strongest in the case of the carbon compounds, because of the relatively large amounts of carbon needed by the growing plant and because of the facility and exactness with which the growth and vitality of the host plant can be experimentally controlled through this phase of its metabolism.

Stakman and his co-workers have studied the light relations of Puccinia graminis tritici inoculated on seedling plants of wheat. Stakman and Piemeisel (1917, p. 487) state that a considerable amount of sunlight is necessary for the best development of the rust. They found that during periods of cloudy weather the incubation period may be lengthened a week or more, and that the rust does not develop so abundantly as during bright weather. Shaded plants invariably were more weakly infected than the others. Partially etiolated plants were infected with difficulty, and the rust developed very weakly on them. No rust developed on etiolated plants. Stakman and Levine (I9I9, p. 7I) found that the rust developed considerably better in fairly high intensities of light than under conditions of less favorable illumination. The size of the urediniospores responded in a similar manner. They summarize their observations on the light relations of the rust as indicating that

... In as much as the photosynthetic activities of the host plant are affected by the light intensity, in so much does the structure and function of the rust depend on the same factor.

\section{Water Relations}

While many observations have been made on the relation of moisture conditions of soil and air to rust virulence on plants in the field, they are subject to criticism in that they do not distinguish between the effect of the moisture conditions on uredospore germination and penetration, and the effect on the vigor of the host and the progress of the rust infection in its tissues. Abundant moisture is always favorable to uredospore germination and infection, but the effect on the physiology of the host is specific for the plant. Abundance of moisture will favor the growth of a mesophyte, but it will have a depressing effect on the vigor of a plant of xerophytic tendencies. Limiting ourselves, therefore, to observations when inoculation was artificially effected under conditions of maximum atmospheric humidity, the evidence permits the inference that the moisture conditions of atmosphere and soil most favorable for the growth of the host plant are likewise optimum for the growth and sporulation of the rust.

The most complete and suggestive experiment is reported by Stakman (1914, p. 35). Wheat plants of both drought-resisting varieties and ordinary mesophytic types were employed, and they were grown in two series. The soil in one series was kept very wet, while that in the other series was kept as dry as possible without endangering the life of the plants. On inoculation with rust, the drought-resisting forms exhibited better infection 
in the dry soil, while the mesophytic types showed'slightly greater virulence of disease in the moist soils. Repeated trials were made with substantially the same result. Stakman concludes:

It is probable then that, conditions having been favorable for a rust infection, the water relation in the soil which is most favorable for the host plant's development is also the most favorable for the development of the rust.

Mains (1917, p. 189) found that the development of $P$. Sorghi on corn, as shown by the number of pustules produced, is favored by a humid atmosphere and by a wet soil-conditions favorable to the growth of the corn plant. The length of the incubation period was not appreciably influenced.

Stakman and Levine (1919, p. 45), in experiments to determine the length of time that wheat seedlings inoculated with $P$. graminis tritici should be kept in a saturated atmosphere in order to obtain maximum infection, found that keeping the plants under a bell jar for more than 48 hours reduced the amount of infection obtained and appreciably lengthened the incubation period. In other experiments (p. 7o) they noted a tendency for excessively high or excessively low humidity during the incubation period to cause a decrease in the size of the urediniospores. In another experiment on soil moisture (p. $7 \mathrm{I}$ ) in which three series of plants were employed, one of which was heavily watered, the second moderately, and the third received only enough water to prevent the plants from wilting, Stakman and Levine found that the plants in the wet soil were more severely attacked and that the urediniospores developed on them were larger than those in the other two series. The plants that suffered from drought produced the smallest spores. The authors conclude as a result of their study on the effect of environmental factors on the morphology of the urediniospore of Puccinia graminis tritici that deficiency of soil moisture and of sunlight and other ecological factors affecting the host plant unfavorably appear to be equally unfavorable to the rust parasite.

\section{Temperature Relations}

There is abundant evidence of a tendency towards physiological parallelism of host and rust in their temperature relations.

Sheldon (1903, p. 33) studied the relation between greenhouse temperature and hours of sunshine per day, and the length of the incubation period in the asparagus rust. His experiments extended over a period of five months, from December, 1900, to May, I901, and yielded data on 132 asparagus plants. The results indicate an inverse relation between the temperature and light conditions under which the host was growing and the incubation period of the rust. During December and January the length of the incubation period was regularly I4 to 17 days. During April and May, when the day was longer, the light better, and the temperature higher, the length of the incubation period was only 8 to ro days. 
Similar experiments with the carnation rust (Puccinia Caryophylli on Dianthus sinensis) gave opposite results. The incubation period increased, from 15 days in January to 21 days in May. In explanation, Sheldon suggests the possibility that the temperature and light in the greenhouse were better suited to the asparagus than to the pinks. In Bailey's Cyclopedia of Horticulture (1914, p. 670) the carnation is characterized as a cool-temperature plant.

Several observers comment on the lengthening of the incubation period in cold weather, and the difficulty of obtaining infection in very warm weather. Christman (1905, p. 106) found that in the cooler weather of spring in Wisconsin the incubation period of cereal rusts is usually lengthened to between three and four weeks. Ward (I902b, p. 233) remarks that, in working with the brown rust of the bromes, he found infection difficult to carry out in hot weather; and in a succeeding paper (1905, p. 4I) he repeats and emphasizes the significance of the observation. In this paper (p. 39), Ward also refers to experiments in which the normal development of the rust was interfered with by warming and chilling the root system of the host plant. Butler and Hayman (1906) describe unsuccessful efforts to produce artificial rust infection on plants growing in the open in the hot weather in India, and express doubts whether the uredospores have power to infect when exposed to temperatures exceeding $100^{\circ} \mathrm{F}$. Fromme (1913) found that temperatures below $20^{\circ} \mathrm{C}$. increased the incubation period of Puccinia coronifera on oats.

Stakman (1914, p. 30), in his culture work with cereal rusts, observed the incubation period to vary with temperature conditions, both high and low temperatures lengthening the period very perceptibly. Mains (19I7, p. I87) observed that low temperatures retarded the development of $P$. coronata and $P$. Sorghi in the host. Stakman and Levine (1919, p. 68) report the optimum temperature for $P$. graminis tritici to be between $66.5^{\circ}$ and $70^{\circ} \mathrm{F}$., this giving the shortest incubation period, the most vigorous infection, and the largest urediniospores, for the host employed. At a higher temperature than $70^{\circ} \mathrm{F}$. the development of the uredinia was retarded at the rate of one day for every Io degrees' rise in temperature, but rust developed at as high a temperature as the host endured although the size of the urediniospores produced was considerably decreased. At low temperatures the development of the uredinia was retarded at the rate of one day for every 5 degrees' fall in temperature. Infection resulted at as low temperatures as the host could stand. The spores at the lower temperatures were rather small, but the difference was not as great as in the case of the high temperatures, with moderate temperatures as the basis for comparison.

Lauritzen (I9I9, p. I9) reports experiments indicating that $42^{\circ} \mathrm{F}$. is below the minimal temperature at which $P$. graminis tritici is able to infect wheat. Above this temperature the amount of infection rises rapidly until 
at $53^{\circ} \mathrm{F}$. it approaches the average for the higher temperatures. The highest temperature at which the rust will produce infection in wheat was found to be $80^{\circ} \mathrm{F}$. under the conditions of the experiments. The figures obtained by Johnson (1912) are cited in evidence that it is not failure of the spores to germinate which determines the infection limits observed in the experiments. Johnson (p. 48) found the optimum temperatures for the germination of the uredospores of the common cereal grain rusts to be low $-12^{\circ}$ to $17^{\circ} \mathrm{C}$.- helping to explain such observations as the difficulty of keeping rust in culture in the greenhouse in the summer, when the incubation period of the rust is shorter than at any other time of the year but it is remarkably difficult to obtain infection; the difficulty of finding viable uredospore material in the spring, the larger number of the spores having already germinated; and the favoring of rust development and epidemics by subnormal temperatures at the critical infection periods in the life of the host plants.

\section{Stimulants and Depressants; Toxic Agents}

Observations on chemical and physical agents stimulating or depressing the vitality of the host plant indicate that susceptibility to rust infection is affected in like manner.

Sheldon (1903, p. 44) found that in the case of the asparagus rust and the carnation rust complete immunity to infection can be produced by lowering the vitality of the host-an end the failure to achieve which in the case of the brown rust of the bromes caused disappointment to Ward. Concerning the asparagus rust, Sheldon states (p. 44):

Attempts have been made repeatedly not only on asparagus but on several species of pinks, to inoculate them when they are not growing well. It was tried on repotted plants, those attacked by insects, and young seedlings. A failure was the result in nearly every case; while with vigorous, growing plants which had become established there were few failures - thirty-seven out of forty-two inoculations made at one time being successful in one instance-approximately 90 percent.

In his experiments with the carnation rust Sheldon (p. 83) found attacks by thrips a very disturbing factor, as it was almost an impossibility to secure infection where the thrips had worked to any extent either before or after inoculation, while vigorously growing plants which were free from thrips were readily inoculated.

Spinks (1913, p. 243) and Voelcker (1912, p. 319) have made observations on the susceptibility to rust of the wheat plants grown in the potculture experiments on the fertilizing effects of small quantities of the salts of the heavy metals conducted at Woburn, England. They found that the lithium salts of the I9I I experiments depressed susceptibility, with the exception of lithium nitrate which gave increased susceptibility to rust. The experiments of 1912 were with zinc salts, and they were all found to produce increased susceptibility to rust, zinc nitrate seeming particularly notable in this respect. 
Stakman (I9I4, p. I5) increased the susceptibility of cereals to rusts to which they are ordinarily highly resistant by slight anaesthetization with ether and chloroform. Jost (1907, p. 195) states that weak etherization accelerates respiration, and such treatment is usually considered as stimulating the metabolism of the plant. Stakman (1914, p. 39) also describes an experiment in which it was sought to influence the susceptibility of wheat plants grown in water cultures by introducing various salts into the culture solution. Copper sulphate, copper carbonate, and iron sulphate were added in varying amounts. The results showed that none of the salts experimented with appreciably decreased the amount of rust when used in such concentration as to permit the normal development of the host plant. Infection was secured on all the plants, even those which were stunted to one sixth their normal size.

Eriksson and Hammarlund (I9I4) report partial success in delaying and inhibiting the development of Puccinia malvacearum on Althea rosea by treating the soil with a 3 to 5 percent solution of copper sulphate. They give no data on the vigor of the plants.

Bailey (1920, p. 76) found that hollyhock plants stunted by red spider showed comparative immunity to rust.

\section{Trauma}

There are only two recorded experiments on the effect of trauma on susceptibility to rust; they do not agree in their findings. Trauma usually has an immediately stimulating effect on the metabolism of a plant tissue and might be expected to increase susceptibility to rust. Hecke (I9I5) mentions that Barfuss working in his laboratory has demonstrated that wheat rust, which ordinarily does not go to rye or barley, readily infects rye and barley leaves if they have previously been injured. After cultivating the rust for seven generations on wounded leaves, Barfuss succeeded in definitely obtaining infections on uninjured leaves; but these did not mature spores. The rust did not lose its power to go back to wheat. This is much after the manner of Salmon's work in increasing the susceptibility of resistant host plants to Erysiphaceous parasites.

Similar efforts to these by Stakman, also working with cereal rusts, gave negative results. Stakman (1914, p. 16) found leaf injury to have no effect on susceptibility to rust.

In one experiment 16 leaves were pricked full of holes in an area of one centimeter or more. They were then inoculated and 4 became flecked, but no pustules developed. Histological examination showed that the spores had sent out germ tubes in large numbers. These grew among the host cells, but true infection did not take place. Sections of these plants were made and examined. It was clearly evident that leaf injury did not increase the chances for infection. 


\section{Age and Maturity of Host Tissue}

In his experiments with the asparagus rust Sheldon (I903, p. 47) found a great difference in susceptibility in favor of young and vigorously growing shoots as against older shoots of the same plant. His observations indicated that

The incubation period of the rust on plants of the same age and growing in the same pot so that conditions were practically identical, was very uniform. When the plants were of the same age and growing in the same kind of soil in different pots, there was still a uniformity. But when there was a difference in maturity, as of two shoots from the same root, or several plants growing in the same pot, there was a difference in the time - of four days in one instance, the young growing shoots showing sori first. The sori showed first on the young growing shoots, and developed faster and to larger size. The more robust the shoot, the larger the sori were and the more spores they produced.

Sheldon found practically no difference between young shoots of young and old plants. A few shoots from three-year-old plants growing in the same pots showed rust the same day that the seedlings did. Sheldon made similar observations on the carnation rust.

An age factor of a different kind is reported by Sheldon (1905, p. 227) in the susceptibility of onions to Puccinia Asparagi. Complete immunity was found when seedling onions were inoculated with the rust. The inoculations were begun as soon as the seedlings appeared above ground, and were repeated at intervals until the seedlings were two months old, when almost every inoculation was successful.

Galloway (1903, p. 208) reports a maturity factor as seemingly affecting the susceptibility of wheat to rust. In his extensive experiments on the possibility of controlling cereal rusts by means of spraying or soil treatment, Galloway found that the rust, while abundant on the primary experimental plots, was absent from nearly all the duplicate plots. The latter had been planted a week to ten days later than the original plots, and in point of growth were at least as much behind them at the time of observation. As the experiments were with a winter wheat, planted the preceding fall, it cannot have been that the plants of the duplicate plots had missed a wave of inoculating material.

Miss Gibson (I904, p. I88) reports the presence of a seasonal factor in the susceptibility of certain varieties of chrysanthemum to the chrysanthemum rust. She noticed that certain varieties do not take the rust in summer, although growing in the midst of plants thickly covered with it. As the rust spores germinate well in summer and the germ tubes penetrate readily, it is a problem not in the physiology of the parasite but rather in that of the host.

Stakman and Piemeisel (I9I7, p. 486), in their extensive inoculation work with cereal and grass rusts, found the cereals and Dactylis glomerata apparently equally susceptible at all ages up to ripening time. Agropyron and Elymus were extremely susceptible when young and much less so when 
older. On the other hand, Phleum pratense and Agrostis alba were more susceptible when older.

Stakman and Levine (1919, p. 73) observed an age difference in the progress of an infection of $P$. graminis avenae on oats. Plants that were one week old at the time of inoculation were somewhat more heavily infected at first than plants one, two, and four weeks older; but at the end of ten days the infection was heavier on the older plants, especially so on the plants that were three weeks old at the time of inoculation. The size of the urediniospores was uniform regardless of the age of the host, nor was any difference observed in the shape and color of the spores. They also state that

... the junior author has obtained very successful infection on mature plants of more than a hundred different varieties of wheat, grown in the greenhouse and artificially inoculated with $P$. graminis tritici.

Giddings (1918, p. 33) found susceptibility in apple leaves to infection by Gymnosporangium juniperi-virginiana to be limited to young leaves, not more than fifteen to twenty-four days old after unrolling from the bud, older leaves being almost completely resistant. H. H. York (personal communication) has found that the very young leaves of Ribes are resistant to infection by Cronartium ribicola, susceptibility not appearing until some time after the unfolding of the leaf.

The factor of age and maturity of host tissue is reviewed here briefly because of its close association in thought with vegetative vigor. There is no necessary physiological connection between the two factors, and their significance in susceptibility and resistance to rust infection is probably of a different nature. The age factor in disease resistance is probably to be classed rather with varietal and constitutional differences than with physiological condition.

\section{Field Studies and Experiments}

A series of studies was made to determine the general facts as to the occurrence and epidemiology of the rusts on the cereal grains in the so called local-flora region of New York, and especially for the New York Botanical Garden and vicinity. Data as to the points involved were found to be very meager, and these preliminary studies were made as a contribution to the general problem of rust epidemiology in the Atlantic States, a field so far little studied because of the relative unimportance of grain growing in these regions. More especially also it was desired to lay a foundation for future studies of rust problems which presuppose a knowledge of the general behavior of the rusts under the climatic and other conditions of the region.

\section{The Rusts of the Cereal Grains and Related Grasses in the Vicinity of New York}

The time of first appearance, period of greatest virulence, and even the identity of the rusts on the cereal grains and related grasses which have been 
suspected of harboring cereal rusts in the vicinity of New York City cannot be regarded as accurately determined.

The herbarium of the New York Botanical Garden contains 17 collections of four different species of rusts on cereal grains and grasses which might bear related rusts from the region about New York City, the so called local-flora region, as follows:

Puccinia rubigo-zera DC. (Puccinia dispersa Eriks. \& Henn. ex parte):

On wheat, at Cedarville, N. J., June 3, 1880. Ellis collection (II).

On rye, at Flatbush, L. I., May 25, I889, by Zabriskie (II).

Puccinia poculiformis (Jacq.) Kuntz (Puccinia graminis Pers.):

On wheat, at Greencastle, Putnam Co., N. Y., September, 1893, by L. M. Underwood (II, III).

On oats, at Greencastle, Putnam Co., N. Y., September, I893, by L. M. Underwood (II, III).

On oats, at the New York Botanical Garden, October, I900, by the class in mycology (II, III).

On Anthoxanthum odoratum, at Newfield, N. J., May 4, I890. Ellis collection (III). On Ammophila brevipile Torr., at Egg Harbor, N. J., 188-, by S. M. Tracy (III).

On Agrostis vulgaris L., at Plainville, Conn., August 23, 1883, by A. B. Seymour (II, III).

On Poa pratensis L., at Greencastle, Putnam Co., N. Y., September, I893, by L. M. Underwood (III).

On Berberis vulgaris L., at Newfield, N. J., May 24, 1875. Ellis collection (I).

On B. vulgaris, at Newfield, N. J., May, 188I. Ellis collection (I).

On B. vulgaris, at Richmond Hill, L. I., May 22, I889, by S. E. Jelliffe (I).

Puccinia andropogonis Schw.:

On Aureolaria villosa (Muhl.) Raf. (Gerardia villosa Muhl.), at Newfield, N. J., June, 1874, by Gerard (I).

On Gerardia quercifolia Pursh., at Westville, Conn., June, 1890, by R. Thaxter (I). Puccinia Ellisiana Thum.:

On Andropogon sp., at Newfield, N. J., September, 1897. Ellis collection (IIJ).

On Andropogon Scoparius Michx., at New Haven, Conn., October 4, I9I3, by J. M. Bates (III).

On Viola pedata L., at New Haven, Conn., May 31, I84I, by Manlius Smith (I).

I have also found the following notes on the occurrence of these forms in the local-flora region. Peck (1871, p. I2I), in his list of the Pucciniae of New York State, lists $P$. coronata Cord. as common on the leaves of grasses and cereals in August and September, and $P$. graminis Pers. as common on the leaves and sheaths of grasses and cereals in autumn and spring. Thaxter (1890, p. 98) notes the abundant occurrence of P. rubigo-vera DC. (probably $P$. dispersa Eriks. and. Henn.) on rye in Connecticut in the year 1890 , describing it as covering the leaves with its rust-covered uredo form and doing considerable damage.

Humphrey (I89I, p. 228) remarks on the occurrence of rust (Puccinia sp.) on rye in Massachusetts in 1891 . He records some interesting observations on the mode of wintering over of the fungus. The rust, he notes, appeared on rye in June so abundantly that the spores rose in clouds when the plants were touched. In July this stage of the fungus had largely 
disappeared, and the winter pustules were mainly in evidence. Observations seemed to indicate that the rust does not survive the winter in its host plant but depends upon fresh infection in the spring on the plots of the Massachusetts Agricultural Experiment Station. In this connection Humphrey notes that uredosori on rye seedlings survived the early frosts and seemed vigorous until the heavy frosts and snowfalls. The plots were then covered with snow until spring. When they were again exposed, the discolored spots where the pustules had been could be readily observed, and examination showed mycelium to be present in the spots; but it was apparently dead, for repeated examination of the plot failed to detect new spores breaking out from any of the old spots. The fungus was not observed after growth was resumed until early in June.

Jelliffe (I 889, p. 35 ) reports Puccinia graminis Pers. on the barberry and on wheat as of frequent occurrence throughout Long Island. Clinton (I903) reports the occurrence in Connecticut of $P$. rubigo-vera DC. (probably $P$. dispersa Eriks. \& Henn.) on rye and barley, of $P$. graminis Pers. on rye, barley, oats, red-top, and timothy, and of $P$. coronata Cord. on the leaves of Rhamnus cathartica, Notoholcus lanatus, and Avena sativa. The outbreaks of the last, Clinton notes, are not nearly so prolonged or prominent as those of $P$. graminis. Burnham and Latham (1914) report finding $P$. coronata Cord. on the leaves of Rhamnus cathartica, Notoholcus lanatus, and Avena sativa at Sothold, L. I. They also report the occurrence there of $P$. graminis Pers. on Berberis vulgaris and on the leaves of various grasses, and of $P$. triticina Eriks. on various species of Triticum.

During the summer and fall of I916 the writer collected the following cereal and grass rusts in the so called "local-flora region," i.e., the region within one hundred miles of New York.

Puccinia dispersa Eriks. \& Henn.:

On wheat, five collections: at Lakehurst, N. J., June 6 (II) and August 23 (II, III); at Yonkers, N. Y., July I6 (II); at New Brunswick, N. J., July 24 (II); at Williamsbridge, N. Y., July I9 to September (II, III); at the New York Botanical Garden, July 17 to October (II, III).

On rye, eight collections: at Tom's River, N. J., June 3 (II, III); at Lakehurst, N. J., June 20 (II, III); at Yonkers, N. Y., July I6 (II); at Queens, L. I., June I5 (II); at New Brunswick, N. J., July 24 (II); at Williamsbridge, N. Y., July I9 (II); at the New York Botanical Garden, July 17 to October: at Nyack, N. Y., July 8 (II).

On barley, two collections: at Williamsbridge, N. Y., September I3 (II); at the New York Botanical Garden, September I5 (II).

On Agropyron repens, three collections: at Tom's River, N. J., July 4 (II); at Williamsbridge, N. Y., July 19 (II); at the New York Botanical Garden, July 8 to October (II, III).

These rusts correspond closely with Eriksson and Henning's Puccinia dispersa (Puccinia rubigo-vera DC. pro parte). The uredo of the abovelisted collections is amphigenous. The number of pustules on the upper surface is somewhat in excess of that on the lower surface, counts on pieces 
of leaf $\mathrm{I} \mathrm{cm}$. in length giving the numbers 174 to 158 , and 217 to 195 respectively. The sori on the upper surface are more pulverulent.

The uredos on the wheat, rye, and Agropyron were certainly not distinguishable by morphological characters. The pustules on the barley show very little pulverulence. Measurements of the pus tules on the barley (measurements being made on the size of the rupture in the epidermis) show them to be of the same size as the pustules on the other hosts of $P$. dispersa. The spores of the barley rust are narrower than those on the other cereals. Twenty-five spores gave an average ratio of length to width of I.218. Seven such measurements on wheat gave ratios ranging from I.083 to 1.163 .

Puccinia graminis Pers.:

On Phleum pratense, at Tom's River, N. J., August 23. Only II was found on this host, as others have noted.

On oats, at Tom's River, N. J., August 23 (II, III); at Williamsbridge, N. Y., August 16 (II, III); at the New York Botanical Garden, August 26 (II, III). The rust was never abundant, occurring as a thin sprinkling on the leaves and sheaths among the crown-rust sori, and on the culms. The long, rectangular, erumpent teleutosori are very conspicuous scattered among the mass of smaller, covered sori of the crown rust.

Puccinia coronifera Kleb.:

On oats, at Williamsbridge, N. Y., August 2 to September (II, III); at the New York Botanical Garden, August I2 to October (II, III); at Tom's River, N. J., August 23 (II, III).

The crown rust of the present collections differs in some minor particulars from the published descriptions I found it somewhat later in its appearance on the sheath, but both uredo and teleuto in the end are as abundant on the sheath as on the leaf blade. Eriksson and Henning (p. 240) found it "rarely on the sheath." Both the uredo and the teleuto occur in abundance on the lower and the upper surfaces of the leaves, but the uredo is always in excess on the upper surface while the teleuto first appears and is always in advance in its development on the under surface. Grove (p. 256) and Fischer (p. 375) describe the teleuto as hypophyllous. The most considerable discrepancy between the descriptions of Grove and Plowright and the rust here described is in the number of the germ pores. Five spores of which the germ pores were counted showed respectively $9,9,9$, II, and 8 pores. The germ pores as well as the spines are inconspicuous until brought out by treatment with lactic acid. Grove (p. 256) and Plowright (p. I64) describe the germ pores as 3 to 4 in number. Fischer (p. 275) simply 1 efers to them as inconspicuous, and Eriksson and Henning (p. 240) do not mention them in their description of the crown rust.

Puccinia impatientis (Schw.) Arth.:

On Elymus virginicus L., at Valley Stream, L. I., August I2 (II); at Hackensack, N. J.,

September 18 (III); at the New York Botanical Garden, June to October (II, III).

At the last-named station Impatiens aurea Muhl. near by was infected 
with an aecidium. The uredospores of this form are markedly less rounded and the teleutosori are much longer than in the case of the wheat and rye rusts as I have found them. The rust on Elymus has, however, been classed with $P$. rubigo-vera DC.

Puccinia poculiformis:

On Cinna arundinacea, at Jerome Avenue, New York City, September I5 (III).

\section{An Experiment to Determine the Time and Method of First Appearance of the Rust, in which the Source and Condition of the Seed as Possible Factors are also Tested}

In investigations of a physiological nature on the cereal rusts it is desirable that the probability be established that, for the variables being compared, the source of the fungus being worked with is constant. This point in experimental method assumes particular importance, in investigations such as are the subject of the present paper, from the recent demonstration of the variation in physiological properties of strains of rust from different localities. Assuming that the rust endemic in any locality is fairly constant in its behavior (whether the constancy is due to actual genetic purity, or to an admixture of strains in constant proportions), a possible source of error would be the seed transmission of the rust, making the source and condition of the seed a factor in determining the nature of the rust. Critical evidence on the question of the rôle played by the seed in the first appearance of rust on cereals in early summer is still lacking. As against the feeling of necessity, almost, in the minds of some investigators, of the assumption of seed transmission of the rusts in explaining certain phenomena in the epidemiology of these diseases, must be counted the inability to demonstrate with certainty a means of transmission, or to observe seed transmission of cereal rusts under controlled experimental conditions.

To test the possible rôle played by the seed in determining the first appearance of rust under field conditions in the vicinity of New York, 25 patches of wheat, 8 patches of barley, one patch of rye, and one patch of oats were planted with seed from widely different sources, and of varying age and condition on a plot of ground near the New York Botanical Garden. The plantings were made on high, well drained land which had not been cultivated since 1912, when it had been put to corn. The nearest plot of cereal was a field of oats about one quarter mile away, and there were no other grain fields within a distance of one mile at least. It is not thought that this single experiment is of very great significance as to the general question of possible seed transmission of rust. It is of interest, however, to include such inferior seed as that planted in the first three plots in a test as to the time of appearance of the rust.

The varieties planted, the source of the seed, and the date the rust first appeared on the plants are shown in table 2. 
TABLE 2

(The designations "screening wheat," "smutted wheat," etc., are the millers' terms)

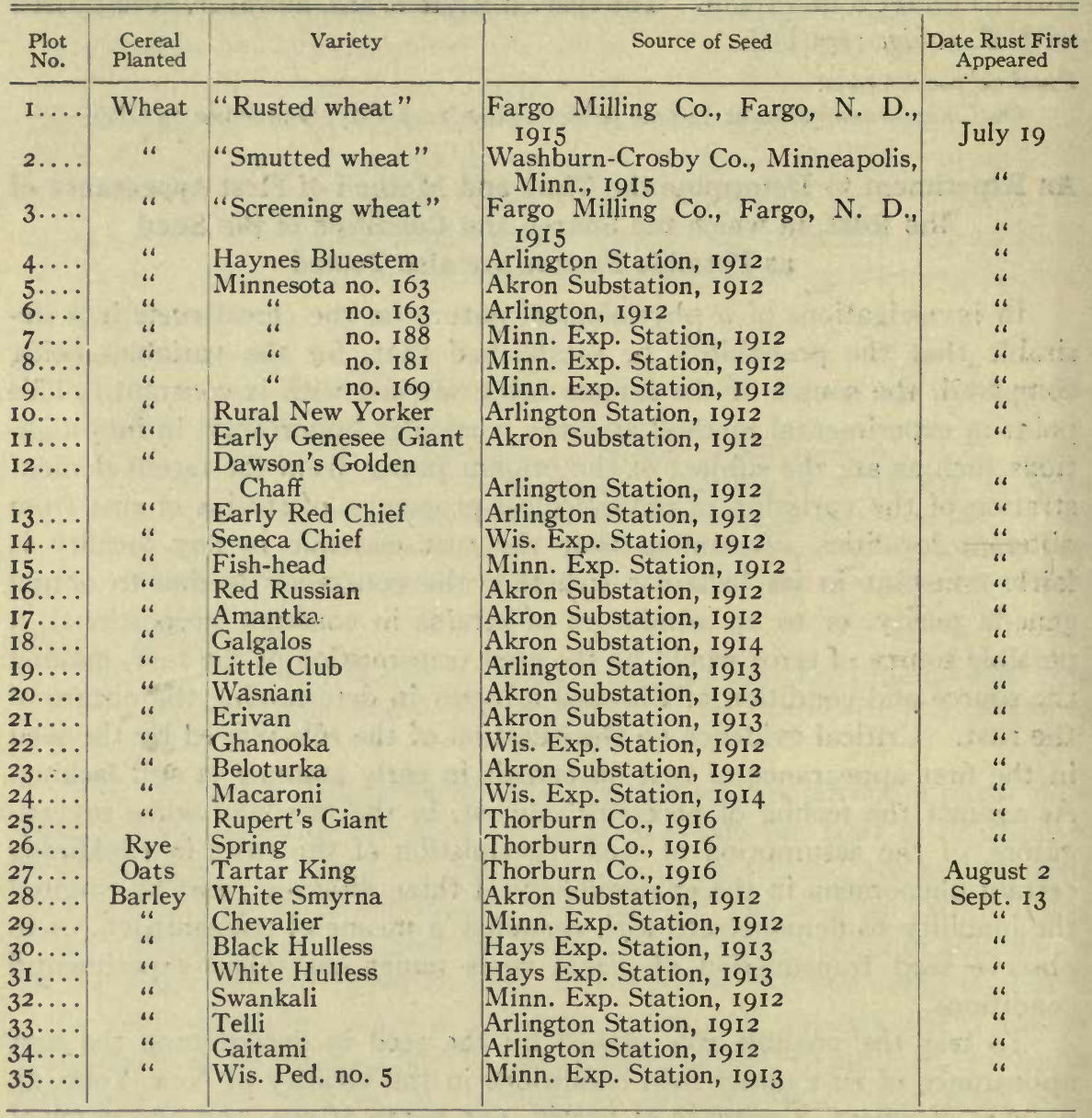

As the table shows, the rust appeared simultaneously on all the plots of wheat and barley respectively. It appeared at the same time on a resistant variety such as the Macaroni wheat and on a susceptible variety such as Rupert's Giant; on plants grown from seed coming from North Dakota and on plants grown from seed coming from Maryland; on plants from good, plump seed and on plants grown from seed rejected by the miller, such as the "rusted wheat" and the "screening wheat" seed. Evidently the nature and first appearance of the rust were determined by local environmental conditions, and variety, age, source, and condition of the seed played a subordinate rôle at least in this particular case. It is also to be noted that the rust appeared at different times on the different cereals except in 
the case of wheat and rye. This may be regarded as further evidence, if any be required, of the physiological distinction of the rubigo-vera forms growing on wheat and rye on the one hand, and on barley and oats on the other.

Hungerford (1920, p. 270) reports an experiment testing the time of first appearance of rust on wheat plants grown from rust-infected and from clean seed, similarly indicating that the condition of the seed does not affect the time of first appearance of the rust. 



\section{VEGETATIVE VIGOR OF THE HOST AS A FACTOR INFLUENCING SUSCEPTIBILITY AND RESISTANCE TO CERTAIN RUST DISEASES OF THE HIGHER PLANTS}

\section{II}

\section{A. Raines}

(Received for publication July I3, I92 I)

\section{Further Field Studies and Experiments}

\section{The Rust History of Plots of Cereals Sown at Successive Intervals through the Summer}

To test the susceptibility to rust of plants of different ages at each period of the summer and of young plants at different times in the summer, and 10 follow the subsequent history of the disease on plantings of cereals started at successive intervals through the season, plots of wheat, rye, (rats, and barley were started in the breeding plot of the New York Botanical ( arden on June Io, June 23, July 6, July 20, August 5, and August 25, I9I6. ()bservations were made at intervals on the height of the plants, the time of first appearance of the rust, the amount of infection, and the proportion (if the rust in the teleuto stage.

The results for the different cereals are shown in table 3 and are discussed lelow. In the table, the days on which the observations were made are g,iven at the top. The height of the plants is given in inches ('). When the plants have headed, it is indicated by an "H." The degree of rust infection is indicated by a numeral, and was estimated on a scale of $\mathrm{I} 0$, the values of the numbers in the scale being: $I=$ an occasional pustule liere and there; most of the leaves not affected. $2=$ most of the leaves with from one to five sori. 3 = about ten pustules on each leaf. $4=$ leaves heavily infected. $5=$ leaves bearing the maximum possible amount (if rust. $6=$ leaf sheaths infected as well as the leaf blades. $7=a$ sprinkling of rust sori on the stem and leaf sheaths; blades heavily infected. $3=$ infection on sheath and stem well developed. $9=$ heavy infection n the stem. Io = heaviest possible infection on the whole plant. The releuto stage is indicated by its Roman numeral, "III." A fraction preceding the "III" gives the proportion of the rust in the teleuto form.

As is indicated in table 3 , the plots of wheat planted on June ro and June 23 headed out in 77 and 64 days respectively. Those planted July 6, July 20, August 5, and August 25 never headed and never exceeded a height of 20 inches. The rust invariably appeared on the young plot as a thin, evenly distributed infection when the host plant was putting out its 
TABLE 3

Wheat

\begin{tabular}{|c|c|c|c|c|c|c|c|c|c|}
\hline \multirow{2}{*}{$\begin{array}{l}\text { Date } \\
\text { Sown }\end{array}$} & \multicolumn{8}{|c|}{ Observations } & \multirow{2}{*}{$\begin{array}{l}\text { No. of Days } \\
\text { to Head }\end{array}$} \\
\hline & July 8 & July 17 & July 24 & Aug. 12 & Aug. 26 & Sept. 15 & Oct. I & Oct. 23 & \\
\hline June $10 . .$. & $8^{\prime \prime}-2$ & $12^{\prime \prime}-4$ & $18^{\prime \prime}-4$ & $24^{\prime \prime}-5$ & $\mathrm{H}-6$ & 7 & $\begin{array}{l}7^{7} \\
\text { slight } \\
\text { III }\end{array}$ & & 77 \\
\hline $\begin{array}{l}\text { June } 23 \ldots \\
\text { July } 6 \ldots \\
\text { July } 20 \ldots \\
\text { Aug. } 5 \ldots \\
\text { Aug. } 25 \ldots\end{array}$ & $2^{\prime \prime}$ & $\begin{array}{l}9^{\prime \prime}-2 \\
5^{\prime \prime}\end{array}$ & $\begin{array}{l}12^{\prime \prime}-4 \\
8^{\prime \prime}-1\end{array}$ & $\begin{array}{l}20^{\prime \prime}-4 \\
15^{\prime \prime}-5 \\
10^{\prime \prime}-3\end{array}$ & $\begin{array}{r}H-5 \\
18^{\prime \prime}-5 \\
12^{\prime \prime}-5 \\
9^{\prime \prime}-3\end{array}$ & $\begin{array}{c}6 \\
\text { slight } \\
\text { III } \\
\text { I } 8^{\prime \prime}-5 \\
15^{\prime \prime}-4 \\
10^{\prime \prime}-4 \\
5^{\prime \prime}-2\end{array}$ & $\begin{array}{l}7 \\
\text { slight } \\
\text { III } \\
20^{\prime \prime}-5 \\
20^{\prime \prime}-5 \\
15^{\prime \prime}-5 \\
9^{\prime \prime}-4\end{array}$ & $\begin{array}{c}6 \\
\text { slight } \\
\text { III } \\
20^{\prime \prime}-4 \\
20^{\prime \prime}-3 \\
15^{\prime \prime}-4 \\
15^{\prime \prime}-3\end{array}$ & 64 \\
\hline
\end{tabular}

Rye

\begin{tabular}{|c|c|c|c|c|c|c|c|c|c|}
\hline \multirow{2}{*}{$\begin{array}{l}\text { Date } \\
\text { Sown }\end{array}$} & \multicolumn{8}{|c|}{ Observations } & \multirow{2}{*}{$\begin{array}{l}\text { No. of Days } \\
\text { to Head }\end{array}$} \\
\hline & July 8 & July 17 & July 24 & Aug. I 2 & Aug. 26 & Sept. 15 & Oct. I & Oct. 23 & \\
\hline $\begin{array}{l}\text { June } 10 . . \\
\text { June } 23 \ldots \\
\text { July } 6 \ldots \\
\text { July } 20 \ldots \\
\text { Aug. } 5 \ldots \\
\text { Aug. } 25 \ldots\end{array}$ & $3^{\prime \prime}$ & $\begin{array}{l}9^{\prime \prime}-2 \\
5^{\prime \prime}\end{array}$ & $\begin{array}{r}20^{\prime \prime}-2 \\
8 "-1\end{array}$ & $\begin{array}{c}\text { de- } \\
\text { stroyed } \\
H-3 \\
15^{\prime \prime}-3 \\
6^{\prime \prime}-1\end{array}$ & $\begin{array}{r}4 \\
\mathrm{H}-5 \\
12^{\prime \prime}-4 \\
4^{\prime \prime}-\mathrm{I}\end{array}$ & $\begin{array}{c}7 \\
6 \\
18^{\prime \prime}-6 \\
10^{\prime \prime}-5 \\
8^{\prime \prime}-2\end{array}$ & $\begin{array}{c}7 \\
7 \\
\mathrm{H}-7 \\
15^{\prime \prime}-6 \\
10^{\prime \prime}-5\end{array}$ & $\begin{array}{c}7 \\
7 \\
6 \\
H-5 \\
20^{\prime \prime}-4\end{array}$ & $\begin{array}{l}33 \\
51 \\
73 \\
79\end{array}$ \\
\hline
\end{tabular}

Oats

\begin{tabular}{|c|c|c|c|c|c|c|c|c|c|}
\hline \multirow{2}{*}{$\begin{array}{l}\text { Date } \\
\text { Sown }\end{array}$} & \multicolumn{8}{|c|}{ Observations } & \multirow{2}{*}{$\begin{array}{l}\text { No. of Day } \\
\text { to Head }\end{array}$} \\
\hline & July 8 & July 17 & July 24 & Aug. 12 & Aug. 26 & Sept. 15 & Oct. I & Oct. 23 & \\
\hline June ro... & $10^{\prime \prime}$ & $14^{\prime \prime}$ & $18^{\prime \prime}$ & $\begin{array}{l}\mathrm{H}-2 \\
\text { slight } \\
\text { III }\end{array}$ & $\begin{array}{l}6 \\
\text { slight } \\
\text { III }\end{array}$ & ${ }_{3 / 4}^{8}$ III & all III & & 77 \\
\hline June $23 \ldots$ & $5^{\prime \prime}$ & $10^{\prime \prime}$ & $18^{\prime \prime}$ & $\begin{array}{l}24^{\prime \prime}-2 \\
\text { slight } \\
\text { III }\end{array}$ & $\begin{array}{c}\mathrm{H}-7 \\
1 / 2 \text { III }\end{array}$ & $\stackrel{8}{3 / 4}$ III & all III & all III & 63 \\
\hline July $6 \ldots$ & & $4^{\prime \prime}$ & $8^{\prime \prime}$ & $\begin{array}{l}\text { 1 } 5^{\prime \prime}-2 \\
\text { slight } \\
\text { IIII }\end{array}$ & $\begin{array}{l}20^{\prime \prime}-6 \\
\text { slight } \\
\text { III }\end{array}$ & $\begin{array}{c}\mathrm{H}-8 \\
2 / 3 \text { III }\end{array}$ & ${ }_{3 / 4}^{8}$ III & $\stackrel{8}{\text { all III }}$ & 70 \\
\hline July $20 \ldots$ & & & & $10^{\prime \prime}-1$ & $\begin{array}{l}\text { I } 2^{\prime \prime}-3 \\
\text { slight } \\
\text { III }\end{array}$ & $\begin{array}{l}18^{\prime \prime}-5 \\
1 / 2 \text { III }\end{array}$ & $\begin{array}{l}24^{\prime \prime}-6 \\
2 / 3 \text { III }\end{array}$ & $\underset{3 / 4 \text { III }}{H-8}$ & 91 \\
\hline Aug. $5 \ldots$ & & & & & $9^{\prime \prime}-1$ & $\begin{array}{l}\text { I } 5 \text { "- } 5 \\
\text { slight }\end{array}$ & $\begin{array}{l}18^{\prime \prime}-5 \\
1 / 4 \text { III }\end{array}$ & $\begin{array}{l}20^{\prime \prime}-7 \\
3 / 4 \text { III }\end{array}$ & \\
\hline Aug. $25 \ldots$ & & & & & & $\underset{6^{\prime \prime}-1}{\text { III }}$ & $10^{\prime \prime}-2$ & $\begin{array}{l}15^{\prime \prime}-5 \\
1 / 3 \text { III }\end{array}$ & \\
\hline
\end{tabular}


Barley

\begin{tabular}{|c|c|c|c|c|c|c|c|c|c|}
\hline \multirow{2}{*}{$\begin{array}{l}\text { Date } \\
\text { Sown }\end{array}$} & \multicolumn{8}{|c|}{ Observations } & \multirow{2}{*}{$\begin{array}{l}\text { No. of Days } \\
\text { to Head }\end{array}$} \\
\hline & July 8 & July 17 & July 24 & Aug. 12 & Aug. 26 & Sept. 15 & Oct. I & Oct. 23 & \\
\hline $\begin{array}{l}\text { June } \text { Io... } \\
\text { June } 23 \ldots \\
\text { July } 6 \ldots \\
\text { July } 20 \ldots \\
\text { Aug. } 5 \ldots \\
\text { Aug. } 25 \ldots\end{array}$ & $\begin{array}{l}8^{\prime \prime} \\
4^{\prime \prime}\end{array}$ & $\begin{array}{r}15^{\prime \prime} \\
15^{\prime \prime} \\
3^{\prime \prime}\end{array}$ & $\begin{array}{l}\mathrm{H} \\
18^{\prime \prime} \\
8^{\prime \prime}\end{array}$ & $\begin{array}{c}\mathrm{H} \\
\mathrm{I}^{\prime \prime \prime} \\
9^{\prime \prime}\end{array}$ & $\begin{array}{c}\mathrm{H} \\
15^{\prime \prime} \\
6^{\prime \prime}\end{array}$ & $\begin{array}{c}2 \\
1 \\
20^{\prime \prime} \\
10^{\prime \prime} \\
6^{\prime \prime}\end{array}$ & $\begin{array}{c}\text { I } \\
3 \\
\text { I } \\
\text { H } \\
\text { I } 5^{\prime \prime} \\
\text { IO" }\end{array}$ & $\begin{array}{c}\text { I } \\
\text { I } 5^{\prime \prime} \\
\text { I2" }\end{array}$ & $\begin{array}{l}44 \\
50 \\
50 \\
70\end{array}$ \\
\hline
\end{tabular}

third leaf. The rust increased steadily in abundance on the leaf blade until it reached the maximum, and only then began to appear on the leaf sheaths. On the stem there were never more than a few scattered pustules. Teleutosori did not appear until the middle of September. They were to he found only on plants of the two oldest plots, and then not without careful search. The observations of October 23 showed a distinct drop in the amount of rust on all the plots of wheat. The new leaf growth of October tended to show but little rust. In view of Johnson's (I912) findings that low temperatures promote uredospore germination, these observations may be interpreted as indicating greater resistance to rust infection on the part of the host tissue due to the decreased rate of metabolic activity consequent on the onset of cooler weather.

All of the plots of rye except that sown August 25 headed out, but the rate of growth varied as is indicated by the successively greater intervals required by the younger stands to head out. The behavior of the rust on the plots of rye was much the same as on the wheat. In the younger plantings it was somewhat less marked and less severe than on the wheat plants of the same age, but the development of the rust was more severe on the rye than on the wheat. It seemed, too, to go more readily to the leaf sheaths and stems in the case of the rye. No teleuto was found on the rye.

Of the oats, the first three plots headed out in 77,65 , and 70 days respectively; the fourth plot produced only one head, 9I days after planting. The plots planted August 5 and August 25 never headed out. No rust appeared on the oats until August 12 when four plots were up, ranging in age from seedlings in the four-leaf stage to plants in bloom. The rust appeared on all four of the plots at the same time and in relatively the same abundance. However, once the rust had appeared, its subsequent history on the various plots differed decidedly. The older the plant, the greater the abundance of rust on it, and the larger proportion of the rust in the teleuto stage.

In the series of barleys, the three older plots headed in 42,50 , and 50 days respectively. The fourth put out a few heads 70 days after planting. 
The last two sowings, of August 5 and August 25, never reached the headingout stage. The barleys were rust-free until the middle of September, when a few uredo pustules were to be discovered on the leaves and sheaths of the three older plots. No teleuto was found.

As has been noted for the plots of wheat and rye, even more strikingly in the case of the oats, the rate of development of the parasite differs with the host. It is much more rapid in the case of the oats than in that of the other cereals. For example, in the seedling stage the amount of rust on the plants may appear less on the oats than on the rye and wheat, although at the time of heading out the same plants will show the reverse condition, the oats being much more severely infected.

The rust history of plots of cereals sown at successive intervals through the summer may be taken as indicating that the age and maturity of the host is a factor in the progress of the disease, and that the action of this factor differs with the identity of the host plant.

\section{Laboratory and Greenhouse Studies}

\section{Culture Methods}

Four cereal rusts-Puccinia coronifera Kleb., $P$. secalina Grove, $P$. triticina Eriks., and P. Sorghi Schw.--were successfully grown for periods of time on the host in pots on greenhouse benches as described by Melhus (I912) and Fromme (1913), and under aseptic conditions on host seedlings growing in test tubes as described by Ward (1902a) and Mains (1917). Variations were introduced in both methods.

Fromme (1913) reviews the problem of growing cereal rusts in the greenhouse. The method recommended by him includes sowing rust spores on new host plants every few weeks by applying them with a scalpel or camel's hair brush, or spraying on in suspension in water with an atomizer, and then putting the host plants into a moist chamber for from 24 to 48 hours to provide the conditions of high humidity necessary for spore germination and infection. Tests, however, indicated that the first part of the method recommended by Fromme, artificially sowing rust spores on the new host, was not necessary under the conditions obtaining in the Columbia greenhouse. It was found that when new host plants are grown beside infected plants in the greenhouse, rust spores will be sown on them by natural agencies, such as convection and other atmospheric currents, sufficient to produce abundant infection if conditions of high humidity are provided occasionally to render possible the germination of the spores.

Accordingly, the method adopted for maintaining stock cultures of the cereal rusts in the greenhouse was to introduce new host plants alongside the infected plants every third week and to cover the cultures with a moist chamber every second or third night. The fungus maintained itself selfsown in this manner, and no artificial inoculations were needed. The 
advantage of such a method of maintaining stock cultures of cereal rusts is that it eliminates the most technical operation, that of sowing or applying the fungous spores to the new host, and reduces the problem of maintaining cereal rusts in culture in the greenhouse to a non-technical routine such as can be entrusted to the average gardener or greenhouse man. -

In growing the rust under aseptic conditions on seedlings in test tubes, the method developed was to treat the seed with chlorine water $(c f$. Wilson, I9I5), put the seed to germinate on filter paper in Petri dishes, and transfer the germinated seed to a test tube plugged with cotton. Half an inch of sterile water was put into the test tube with the plant. The reserve food materials of the endosperm are capable of bringing the seedling to the third leaf stage, which is sufficient to raise a generation of the rust on it. $P$. coronifera was cultivated for Io generations in this manner, transfers being made once a month; $P$. Sorghi for 8 generations; $P$. triticina for 8 generations; and $P$. secalina for 6 generations. A small platinum spatula was employed for making transfers; spores were applied to the upper surface of the first leaf in each case, and material for inoculum was taken from the under surface. That a cereal rust can thus be grown under conditions free from accidental contamination was indicated by the total absence of organic growth, bacterial or fungous, when a rust-infected seedling was deposited on sterile beef-peptone agar.

\section{Studies on the Incidence of Infection by Measured Doses of Uredospores of Puccinia Sorghi on Zea Mays}

An effort was made to determine the minimal dose of uredospores of P. Sorghi that (I) can possibly, and (2) will certainly produce infection in Zea Mays. I9I tests were made on corn seedlings growing under aseptic conditions in twelve-inch test tubes.

The method employed to determine the dose and to inoculate was as follows: A dilute suspension of uredospores was made in a vial of sterile water. A small drop from this suspension was put on a piece of sterile cover slip, and the number of uredospores in the drop was counted under the microscope. The piece of cover glass was then inverted and deposited on the upper surface of the first leaf of the young corn seedling in the test tube, about one half inch below the tip, bringing the drop of water containing the known number of uredospores in contact with the host tissue. The work was done in the winter in the laboratory, with no rust growing free anywhere in the building, so that the danger of accidental contamination was negligible. No infection ever developed on the seedlings except on the spot where the plant had been inoculated.

The inoculated seedlings were kept under observation for $2 \mathrm{I}$ days. If the inoculated leaf yellowed or withered before 15 days, the plant was discarded. The data on I9I tests are shown in table 4. 
TABLE 4

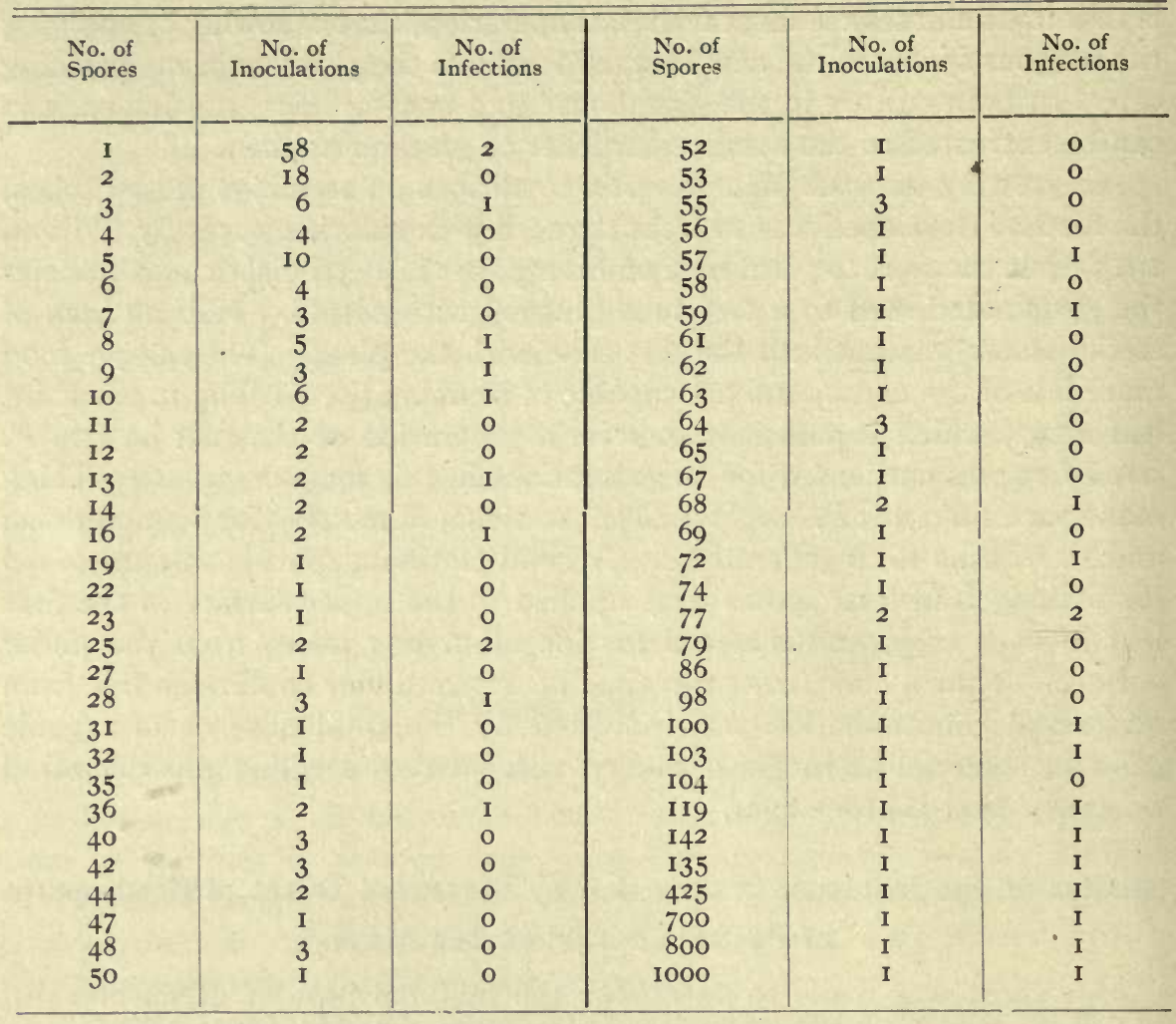

The results cannot be considered as entirely convincing in view of the many factors involved in a successful inoculation. The evidence indicates, however, that, as to the minimal number of uredospores which can possibly produce infection, it is possible for a single uredospore to produce infection. In each of the two cases in which infection was produced after inoculation with a single uredospore, the rust appeared after the usual incubation period as a very small pustule at the point of inoculation. In one case the infected leaf withered shortly after the appearance of the pustule; in the other instance the mycelium showed normal growth, and about a week later seven new uredosori were produced in a ring around the first pustule.

As regards the second question, the minimal dose of uredospores which will certainly produce infection, the data indicate this to be, for the conditions under which the work was done, between 100 and 125. This is high. In view of the varying viability of spores taken at one time from the same pustule, and of their further variation with the age of the pustule, it was not considered possible actually to test the germination for each sample used. However, the spores were always taken from the surface of a large and pulverulent sorus, and, considering that the index of germination 
of the uredospores under the conditions of inoculation was from 75-90 percent, and that it is possible for a single spore to produce infection, we can say that (taking the conservative germination figure of 50 percent) of more than fifty spores germinating on the surface of the leaf, only one produced successful infection. Evidently, successful infection by a uredospore involves other factors besides that of germination on the leaf surface of the host plant.

\section{The Constitution of the Fungous Mycelium as a Factor in Teleutospore Production by Puccinia coronifera}

Our knowledge of the conditions governing teleutospore production in the cereal rusts is summarized and extended by Gassner (I9I5), who considers that the determining factor is the physiological aging of the host tissue, teleutospore production being particularly coincident with the mobilization of the food resources of the plant for flower and fruit production. The picture of teleutospore production presented by the plants of the experimental field plots described above closely parallels Gassner's observations in similar experiments and is consistent with his views.

Consideration of the behavior of Puccinia coronifera as regards teleutospore production, when grown in the greenhouse, leads to the suggestion that the protoplasmic constitution of the fungous mycelium may be a factor. Greenhouse cultures of the rust from material brought in from the field in the vicinity of New York exhibited moderate teleutospore production. A series of cultures from material sent the writer by J. I. Durrell from Ames, Iowa, on the other hand, grown at the same time on similar host material and under similar conditions, showed very abundant teleutospore production, the difference in this respect between the two series of cultures being readily noticeable. While such teleutospore production on potted oat seedlings in the greenhouse is more commonly on the older infected leaves, which are yellowing at the tip, it is not unusual to observe the production of teleutospores by rust pustules on young and vigorous leaves shortly after first infection.

Experiment showed that it is readily possible to secure variation in the tendency of the rust towards teleutospore production by selection. The rust was grown in test tubes under aseptic conditions. Large variation in the tendency towards teleutospore production was noted in cultures of the third generation, some rust cultures showing no teleutosori at all; in others as much as 75 percent of the pustules were teleutosori. Two series of cultures were therefore propagated. In one of the series, transfers were made from cultures showing no teleutospores. Of 36 cultures in this series, 20 showed complete absence of teleutosori; only 2 of the cultures developed more than 50 percent of the winter stage.

In the second series, transfers were made from cultures showing 75 percent teleutosori. Of 35 cultures in this series, 30 showed more than 
50 percent teleutosori, and only 5 less than that. Two of the cultures in this series never produced any uredospores whatever, teleutosori only being developed. It was obviously impossible to make transfers from such cultures.

Figure 3, Plate XII, shows a rust mycelium in which only the first pustule produced uredospores, succeeding pustules bearing only teleutospores.

Apparently there may be wide differences in the tendency towards the production of teleutospores in different cultures of a rust fungus, and the factor of fungous constitution should be given consideration in work on the conditions of teleutospore production.

\section{Nutrition and Growth Studies}

\section{Water Cultures}

Six experiments were performed with Puccinia Sorghi on corn to test the effect on rust development of growing the host plants in culture solutions of varying nutritive value. A sugar corn was used, as being more susceptible to rust than a flint or dent corn. The seedlings were grown in water culture in 250-cc. Erlenmeyer flasks. Knop's nutrient solution was used as a base. Except as otherwise noted, the endosperm was removed about the time that the first leaf was breaking through the coleoptile, so that the plant was entirely dependent for sustenance on the mineral salts it could obtain from the nutrient solution and on the carbohydrates it could manufacture in its leaf tissue. Inoculation was effected by spraying with a suspension of uredospores and covering with a bell jar for 24 hours. Observations were made on the incubation period and on the progress of the disease on the plants. The dry weight of the top of the plant at the conclusion of the experiment was taken as an index of the relative vigor of growth of the plant.

TABLE 5

Exp. I. Effect of Renewing Solution. Plants Inoculated February 28, 1919.

\begin{tabular}{|c|c|c|c|c|c|}
\hline \multirow{2}{*}{$\begin{array}{l}\text { No. of } \\
\text { Plant }\end{array}$} & \multirow{2}{*}{$\begin{array}{l}\text { Treat- } \\
\text { ment }\end{array}$} & \multirow{2}{*}{$\begin{array}{l}\text { Dry Weight } \\
\text { of Top } \\
\text { of Plant } \\
\text { in Mg. }\end{array}$} & \multicolumn{3}{|c|}{ Observations } \\
\hline & & & March 9 & March II & March $\mathrm{I}_{3}$ \\
\hline I.... & $\begin{array}{l}\text { Solut io n } \\
\text { changed once } \\
\text { a week }\end{array}$ & 340 & 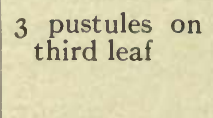 & $\begin{array}{l}\text { I pustule on } \\
\text { second leaf; } \\
3 \text { pustules on } \\
\text { third leaf }\end{array}$ & $\begin{array}{l}2 \text { pustules on second } \\
\text { leaf; } 3 \text { pustules on } \\
\text { third leaf }\end{array}$ \\
\hline & $\begin{array}{l}\text { Solution not } \\
\text { changed }\end{array}$ & 310 & No infection & $\begin{array}{l}\text { I pustule on } \\
\text { second leaf }\end{array}$ & $\begin{array}{l}\text { I pustule on first leaf; } \\
4 \text { pustules on second } \\
\text { leaf; I pustule on } \\
\text { fourth leaf }\end{array}$ \\
\hline $3 \ldots$ & $\begin{array}{l}\text { Solution not } \\
\text { changed }\end{array}$ & 280 & No infection & No infection & $\begin{array}{l}\text { I pustule on first leaf; } \\
\text { I pustule on third } \\
\text { leaf }\end{array}$ \\
\hline
\end{tabular}


Exp. 2. Effect of Removing Endosperm. Plants Inoculated February 28, 19I9.

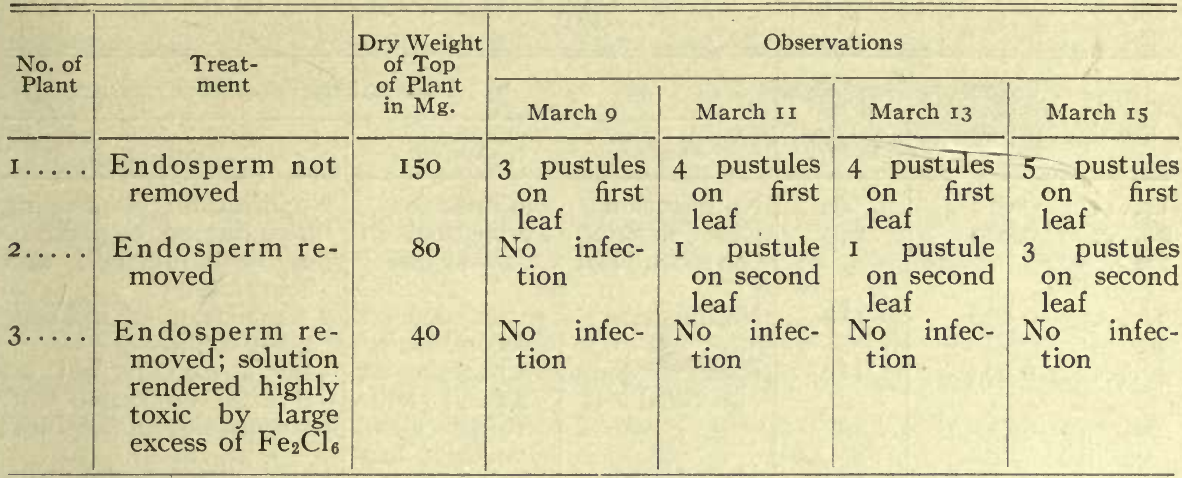

Exp.3. Effect of Culture Solutions of Varying Nutritive Value. Plants Inoculated March I9, IOIO.

\begin{tabular}{|c|c|c|c|c|c|c|}
\hline \multirow{2}{*}{$\begin{array}{l}\text { No. of } \\
\text { Plant }\end{array}$} & \multirow{2}{*}{$\begin{array}{l}\text { Treat- } \\
\text { ment }\end{array}$} & \multirow{2}{*}{$\begin{array}{l}\text { Dry Weight } \\
\text { of Top } \\
\text { of Plant } \\
\text { in Mg. }\end{array}$} & \multicolumn{4}{|c|}{ Observations } \\
\hline & & & March 25 & March 26 & March 27 & March 29 \\
\hline I.... & $\begin{array}{l}\text { Full nutrient solu- } \\
\text { tion; endosperm } \\
\text { not removed }\end{array}$ & 160 & $\begin{array}{l}\text { Infection } \\
\text { on second } \\
\text { and third } \\
\text { leaves }\end{array}$ & $\begin{array}{l}\text { Infection } \\
\text { on second } \\
\text { and third } \\
\text { leaves }\end{array}$ & $\begin{array}{l}\text { I3 pustules } \\
\text { on second } \\
\text { leaf; } 4 \\
\text { pustules } \\
\text { on third } \\
\text { leaf }\end{array}$ & $\begin{array}{l}2 \text { pustuleson } \\
\text { first leaf; I } \\
\text { pustule on } \\
\text { s e c o n d } \\
\text { leaf; } 7 \text { pus- } \\
\text { tules on } \\
\text { third leaf }\end{array}$ \\
\hline $2 \ldots \ldots$ & $\begin{array}{l}\text { Full nutrient solu- } \\
\text { tion }\end{array}$ & 80 & $\begin{array}{l}\text { No infec- } \\
\text { tion }\end{array}$ & $\begin{array}{l}\text { No infec- } \\
\text { tion }\end{array}$ & $\begin{array}{l}3 \text { pustules } \\
\text { on first } \\
\text { leaf; } 4 \\
\text { pustules } \\
\text { on second } \\
\text { leaf }\end{array}$ & $\begin{array}{l}5 \text { pustules } \\
\text { on first } \\
\text { leaf; } 5 \\
\text { pust ules } \\
\text { on second } \\
\text { leaf }\end{array}$ \\
\hline & $\begin{array}{l}\text { Full nutrient solu- } \\
\text { tion }\end{array}$ & 80 & $\begin{array}{l}\text { No infec- } \\
\text { tion }\end{array}$ & $\begin{array}{l}\text { No infec- } \\
\text { tion }\end{array}$ & $\begin{array}{l}\text { I pustule } \\
\text { on first } \\
\text { leaf; } 2 \\
\text { pustules } \\
\text { on second } \\
\text { leaf; I } \\
\text { pust ule } \\
\text { on third } \\
\text { leaf }\end{array}$ & $\begin{array}{l}3 \text { pustules } \\
\text { on first } \\
\text { leaf; } 4 \\
\text { pust ules } \\
\text { on second } \\
\text { leaf; } 2 \\
\text { pust ules } \\
\text { on third } \\
\text { leaf }\end{array}$ \\
\hline $4 \ldots$ & $\begin{array}{l}\text { Nutrient solution } \\
\text { rendered toxic } \\
\text { with excess of } \\
\mathrm{Fe}_{2} \mathrm{Cl}_{6}\end{array}$ & 50 & $\begin{array}{l}\text { No infec- } \\
\text { tion }\end{array}$ & $\begin{array}{l}\text { No infec- } \\
\text { tion }\end{array}$ & $\begin{array}{l}2 \text { pustules } \\
\text { on second } \\
\text { leaf }\end{array}$ & $\begin{array}{l}2 \text { pustules } \\
\text { on second } \\
\text { leaf; I I } \\
\text { pustule on } \\
\text { third leaf }\end{array}$ \\
\hline $5 \ldots$ & Tap water & 40 & $\begin{array}{l}\text { No infec- } \\
\text { tion }\end{array}$ & $\begin{array}{l}\text { No infec- } \\
\text { tion }\end{array}$ & $\begin{array}{l}\text { I pustule } \\
\text { on first } \\
\text { leaf; } 2 \\
\text { pustules } \\
\text { on third } \\
\text { leaf }\end{array}$ & $\begin{array}{l}2 \text { pustules } \\
\text { on first } \\
\text { leaf; } \\
\text { pust ules } \\
\text { on second } \\
\text { leaf; I } \\
\text { pustule on } \\
\text { third leaf }\end{array}$ \\
\hline $6 \ldots$. & Distilled water & 20 & $\begin{array}{l}\text { No infec- } \\
\text { tion }\end{array}$ & $\begin{array}{l}\text { No infec- } \\
\text { tion }\end{array}$ & $\begin{array}{l}\text { No infec- } \\
\text { tion }\end{array}$ & $\begin{array}{l}2 \text { pustules } \\
\text { on second } \\
\text { leaf }\end{array}$ \\
\hline $7 \ldots$ & $\begin{array}{l}\text { Highly toxic nu- } \\
\text { trient solution }\end{array}$ & 20 & $\begin{array}{l}\text { No infec- } \\
\text { tion }\end{array}$ & $\begin{array}{l}\text { No infec- } \\
\text { tion }\end{array}$ & $\begin{array}{l}\text { No infec- } \\
\text { tion }\end{array}$ & $\begin{array}{l}\text { I pustule on } \\
\text { first leaf }\end{array}$ \\
\hline
\end{tabular}


Exp. 4. Effect of Varying Concentration of Nutrient Solution. Plants Inoculated April 2, 1919

\begin{tabular}{|c|c|c|c|c|c|}
\hline \multirow{2}{*}{$\begin{array}{l}\text { No. of } \\
\text { Plant }\end{array}$} & \multirow{2}{*}{$\begin{array}{l}\text { Concen- } \\
\text { tration of } \\
\text { Nutrient } \\
\text { Solution }\end{array}$} & \multirow{2}{*}{$\begin{array}{l}\text { Dry Weight } \\
\text { of Top } \\
\text { of Plant } \\
\text { in Mg. }\end{array}$} & \multicolumn{3}{|c|}{ Observations } \\
\hline & & & April 8 & April 9 & April 14 \\
\hline & 0.012 & 20 & No infection & No infection & No infection; plant dying \\
\hline & 0.009 & 140 & $\begin{array}{l}\text { Rust showing } \\
\text { on second leaf }\end{array}$ & $\begin{array}{l}\text { I } 2 \text { pustules on } \\
\text { second leaf }\end{array}$ & $\begin{array}{l}\text { Large number of pustules } \\
\text { on first, second, and } \\
\text { third leaves }\end{array}$ \\
\hline 3. & 0.006 & 110 & No infection & $\begin{array}{l}3 \text { pustules on } \\
\text { second leaf }\end{array}$ & $\begin{array}{l}5 \text { pustules on second leaf; } \\
\text { plant dying }\end{array}$ \\
\hline 4.. & 0.003 & 110 & $\begin{array}{l}\text { Rust showing } \\
\text { on third leaf }\end{array}$ & $\begin{array}{l}\text { I9 pustules on } \\
\text { second leaf; } \\
\text { Io pustules } \\
\text { on third leaf }\end{array}$ & $\begin{array}{l}5 \text { pustules on first leaf; } 20 \\
\text { pustules on second leaf; } \\
\text { 1o pustules on third leaf }\end{array}$ \\
\hline & 0.0015 & 100 & No infection & No infection & $\begin{array}{l}\text { I7 pustules on first leaf } \\
8 \text { pustules on second leaf }\end{array}$ \\
\hline 6. & $\begin{array}{l}\text { Distilled } \\
\text { water }\end{array}$ & (de & stroyed) & & \\
\hline
\end{tabular}

In all the water-culture experiments (table 5) an increase in the incubation period of the rust with depression in the vigor and rate of growth of the host plant was apparent. Coincident with the increased incubation period of the rust on host plants of poor growth and little vigor went always a marked depression in the luxuriance of the fungus. The pustules were appreciably smaller, and produced decidedly fewer spores.

Comparing the incubation period of the rust on the leaves of the same plant, it is found to be shorter on the younger leaves. Comparing the first and second leaves, we find:

Infection noted on the first leaf before it appeared on second leaf. . . o

Infection noted simultaneously on first and second leaves . . . . . . 5

Infection noted on second leaf before first. . . . . . . . . . . . 7

Infection on first leaf; none on second ................ 2

Infection noted on second leaf; none on first .............. 7

The older host tissue, it would seem, provided a less congenial environment for the development of the rust.

Incidental to the above-described water-culture experiments was the demonstration of the ability of the rust to develop on chlorotic tissue. Some corn seedlings were grown in iron-free nutrient solution, and the fourth and fifth leaves produced by the plants were completely blanched. The plants were sprayed with a spore suspension to test the susceptibility of these leaves to the rust. Nine days after inoculation the chlorotic leaves showed abundant rust infection. Giddings (personal communication) has obtained infection with Gymnosporangium juniperi-virginianae on apple leaves blanched by being kept in the dark room while unfolding from the bud. It may be concluded that the presence of chlorophyll is not a necessary condition for rust development. 


\section{Soil Cultures}

From the studies of Sheldon, Ward, and Stakman, as also from the experiments described above, it may be considered as established that, within the range of forms worked with, conditions unfavorable to the growth of the host cause an increase in the incubation period of the rust and depress the luxuriance of growth of the fungous mycelium as indicated by the size of the pustules and the number and size of the spores produced in them.

Concerning the effect of conditions unfavorable to the growth of the host on the incidence of rust infection-the number of successful infections produced on a unit area of host tissue by a given dose of inoculum-our knowledge must be regarded as not so definite. The data extant are subject to criticism because of the relatively small number of variables studied and because of the irregularity of dosage inherent in the method of inoculation employed. Ward (1902) applied spores to the leaf by means of a swab of cotton, and Stakman (I9I4, p. II) employed a flat inoculating needle for this purpose.

Studies on the relation between host vigor and incidence of infection, to be of critical value, must be made with numbers of variables sufficient to preclude undue distortion of the results by fluctuations in condition of host and fungus, and by errors in the taking and studying of data; the method of inoculation employed must stand criticism as to the uniformity of dosage for the variables compared; and, if any but the grossest relations between the variables studied are to be made apparent, a more exact basis than visual observation and judgment must be employed for determining vigor of growth of host plant and degree of rust infection on it.

In the experiments described below on the relation between host vigor in the oat plant and its susceptibility to crown rust, data were obtained on I 450 individual plants receiving different nutritive treatment and exhibiting wide variation in vigor of growth. The plants were grown in pots in the greenhouse. Inoculation was effected under natural field conditions by placing the pots containing the experimental plants out of doors near a stand of oats heavily infected with crown rust. Analysis of the data indicates that the dosage for the variables compared was uniform. The experiments were concluded and the readings taken before the rust on any of the plants approached the maximum that the leaf tissue could support, so that the infection present at the time may be considered an index of the response of the host tissue to the conditions of inoculation to which it was subjected, and variation in this response between host tissues receiving similar doses of inoculum was presumably due to differences in the condition of the tissues compared.

Values for the vigor of the host plant and for the amount of rust infection present on it were obtained as follows: At the conclusion of the experiment the plant was cut off at the base and observations were taken 
of the number of rust pustules on the upper surface of each leaf, of the length of each leaf in inches, of the extreme length of the entire plant, and of the number of stools it had produced. The plant was then dried, and its dry weight was obtained. The dry weight of the plant was adopted as the index of its relative vigor of growth, because it makes possible more accurate seriation of the variables on this value than an index such as the height of the plant or the total leaf length.

As an index of the degree of infection of the plant the value adopted was the number of pustules on an average unit area of the most severely infected leaf - calculated by dividing the number of rust pustules on the leaf by the length of the leaf in inches, and by its width at the base in sixteenths of an inch. This value was found to have a positive correlation $(r=.7803 \pm .0167$ for the 250 variables of experiments I, II, and III) with the value that at first thought would seem most desirable: namely, the total number of rust pustules counted on the leaves of the plant, divided by the total leaf length in inches, and by the largest leaf width in sixteenths of an inch-and is preferable for adoption in work of this kind not only because it is easier to obtain, but also because it avoids the error introduced by the development of new leaf surface during the incubation period. The most highly infected leaf on the plant was usually the lowest leaf in good condition. In tables 6-Io both values are given.

\section{Experiment I}

66 oat plants were grown in soil in 2 -inch pots, divided into three groups on the basis of the number of plants grown to a pot. The soil was a rich garden loam. The seed was sown July 6 , I920, three grains being put in to the soil for every plant desired, and the seedlings were later thinned out to the number of plants desired. The pots were kept on a bench in the greenhouse until August II, when they were taken out of doors and set near a patch of rusty oats, subjecting the plants to natural conditions of inoculation and infection. The experiment was concluded on August 24. The data on this experiment are given in table 6 .

TABLE 6

\begin{tabular}{|c|c|c|c|c|c|}
\hline Group & $\begin{array}{c}\text { No. of } \\
\text { Variables }\end{array}$ & $\begin{array}{l}\text { No. of } \\
\text { Plants to a } \\
\text { 2-inch Pot }\end{array}$ & $\begin{array}{l}\text { Mean } \\
\text { Dry Weight } \\
\text { of Top of } \\
\text { Plant } \\
\text { in Mg. }\end{array}$ & $\begin{array}{l}\text { Mean No. of } \\
\text { Pustules } \\
\text { per Ave. Unit } \\
\text { Area of Total } \\
\text { Leaf Surface }\end{array}$ & $\begin{array}{l}\text { Mean No. of } \\
\text { Pustules } \\
\text { per Ave. Unit } \\
\text { Area of most Severely } \\
\text { Infected Leaf }\end{array}$ \\
\hline $\begin{array}{l}a \\
b \\
c\end{array}$ & $\begin{array}{l}23^{*} \\
18 \\
25\end{array}$ & $\begin{array}{l}5 \\
2 \\
1\end{array}$ & $\begin{array}{r}61 \\
135 \\
183\end{array}$ & $\begin{array}{l}1.1 \\
2.1 \\
2.3\end{array}$ & $\begin{array}{l}4.2 \\
6.0 \\
6.1\end{array}$ \\
\hline
\end{tabular}

\section{Experiment II}

70 plants were grown in 3 -inch pots, divided in to three groups on the basis of the number of plants grown to a pot. Soil, method of seeding, and dates

* Plus 2 destroyed. 
of sowing, setting out of doors to be inoculated, and of concluding the experiment were the same as in experiment I described above. The results are shown in table 7 .

TABLE 7

\begin{tabular}{c|c|c|c|c|c}
\hline Group & $\begin{array}{c}\text { No. of } \\
\text { Variables }\end{array}$ & $\begin{array}{c}\text { No. of } \\
\text { Plants to a } \\
\text { 3-inch Pot }\end{array}$ & $\begin{array}{c}\text { Mean } \\
\text { Dry Weight } \\
\text { of Top of } \\
\text { Plant } \\
\text { in Mg. }\end{array}$ & $\begin{array}{c}\text { Mean No. of } \\
\text { Pustules } \\
\text { per Ave. Unit } \\
\text { Area of Total } \\
\text { Leaf Surface }\end{array}$ & $\begin{array}{c}\text { Mean No. of } \\
\text { Pustules } \\
\text { per Ave. Unit } \\
\text { Area most Severely } \\
\text { of }\end{array}$ \\
\cline { 1 - 5 }$a$ & 25 & 5 & 96 & 1.6 & 4.1 \\
$b$ & 20 & 2 & 264 & 1.7 & 4.8 \\
$c$ & 25 & I & 407 & 2.0 & 5.2 \\
\hline
\end{tabular}

\section{Experiment III}

I20 plants were grown in $4 \frac{1}{2}$-inch pots, divided into four groups on the basis of the number of plants grown to a pot. Soil, method of seeding, and dates of sowing, of setting out-doors to be inoculated, and of concluding the experiment were the same as in experiment I. Results are given in table 8 .

TABLE 8

\begin{tabular}{|c|c|c|c|c|c|}
\hline Group & $\begin{array}{l}\text { No. of } \\
\text { Variables }\end{array}$ & $\begin{array}{c}\text { No. of } \\
\text { Plants to a } \\
4 \frac{1}{2} \text {-inch Pot }\end{array}$ & $\begin{array}{l}\text { Mean } \\
\text { Dry Weight } \\
\text { of Top } \\
\text { of Plant } \\
\text { in Mg. }\end{array}$ & $\begin{array}{l}\text { Mean No. of } \\
\text { Pustules } \\
\text { per Ave. Unit } \\
\text { Area of Total } \\
\text { Leaf Surface }\end{array}$ & $\begin{array}{c}\text { Mean No. of } \\
\text { Pustules } \\
\text { per Ave. Unit } \\
\text { Area of most Severely } \\
\text { Infected Leaf }\end{array}$ \\
\hline $\begin{array}{l}a \\
b \\
c \\
d\end{array}$ & $\begin{array}{l}50 \\
25 \\
20 \\
25\end{array}$ & $\begin{array}{r}10 \\
5 \\
2 \\
1\end{array}$ & $\begin{array}{l}161 \\
352 \\
661 \\
976\end{array}$ & $\begin{array}{l}1.5 \\
2.4 \\
2.7 \\
2.5\end{array}$ & $\begin{array}{l}3.6 \\
6.4 \\
6.5 \\
6.2\end{array}$ \\
\hline
\end{tabular}

\section{Experiment IV}

600 oat plants were grown in $4 \frac{1}{2}$-inch pots, 5 plants to a pot; 15 grains being planted in each pot in the first place, and the young seedlings thinned out to the desired number. The plants were divided into six groups of Ioo individuals each on the basis of soil composition and treatment, as follows:

Group A: Soil composed of sand only.

Group B: Soil a mixture of $\frac{4}{5}$ sand and $\frac{1}{5}$ garden loam.

Group C: Soil a mixture of $\frac{1}{2}$ sand and $\frac{1}{2}$ garden loam.

Group D: Soil the same mixture as in Group C. In addition, $\mathrm{KCl}$ at the rate of 350 pounds to the 6 -inch acre of $2,000,000$ pounds was intimately mixed with the soil.

Group E: Soil the same mixture as in Group C. In addition, acid phosphate at the rate of 750 pounds to the acre was intimately mixed with the soil.

Group F: Soil the same mixture as in Group C. In addition, sodium nitrate at the rate of 500 pounds to the acre was intimately mixed with the soil.

Seed was sown July II, I920. On July 24, July 3I, and August 7 the plants of groups $D, E$, and $F$ had additional quantities of fertilizer applied 
in water solution at the rate of Ioo pounds to the acre. On August 9 the plants were placed out of doors to be inoculated. The experiment was concluded on August 27. Figures I and 2, Plate XI, illustrate the growth differences obtained between the plants of the different groups in these experiments.

In table 9, the groups are arranged in order of the vigor of growth exhibited by the plants.

TABLE 9

\begin{tabular}{|c|c|c|c|c|c|}
\hline Group & $\begin{array}{l}\text { No. of } \\
\text { Variables }\end{array}$ & $\begin{array}{l}\text { Soil } \\
\text { Treatment }\end{array}$ & $\begin{array}{l}\text { Mean } \\
\text { Dry Weight } \\
\text { of Top } \\
\text { of Plant } \\
\text { in Mg. }\end{array}$ & $\begin{array}{l}\text { Mean No. of } \\
\text { Pustules } \\
\text { per Ave. Unit } \\
\text { Area of Total } \\
\text { Leaf Surface }\end{array}$ & $\begin{array}{c}\text { Mean No. of } \\
\text { Pustules } \\
\text { per Ave. Unit } \\
\text { Area of most Severely } \\
\text { Infected Leaf }\end{array}$ \\
\hline$A$ & 100 & sand & 120 & .6 & 2.0 \\
\hline$E$ & 100 & $\begin{array}{l}\text { acid } \\
\text { phosphate }\end{array}$ & I 55 & .8 & 2.7 \\
\hline$B$ & 100 & $\frac{4}{5}$ sand & 200 & .7 & 2.3 \\
\hline$D$ & 100 & $\mathrm{KCl}$ & 202 & 1.0 & 3.2 \\
\hline$C$ & 100 & $\frac{1}{2}$ sand & $34 \mathrm{I}$ & .9 & 3.1 \\
\hline$F$ & 100 & $\mathrm{NaNO}_{3}$ & 564 & 1.2 & 4.5 \\
\hline
\end{tabular}

\section{Experiment $V$}

This was a duplicate of Experiment IV, started a week later. The seed was sown July I7, the plants were placed out of doors to be inoculated August 10, and the experiment was concluded August 3I. The results are shown in table 10.

TABLE IO

\begin{tabular}{|c|c|c|c|c|c|}
\hline Group & $\begin{array}{c}\text { No. of } \\
\text { Variables }\end{array}$ & $\begin{array}{l}\text { Soil } \\
\text { Treatment }\end{array}$ & $\begin{array}{l}\text { Mean } \\
\text { Dry Weight } \\
\text { of Top } \\
\text { of Plant } \\
\text { in Mg. }\end{array}$ & $\begin{array}{l}\text { Mean No. of } \\
\text { Pustules } \\
\text { per Ave. Unit } \\
\text { Area of Total } \\
\text { Leaf Surface }\end{array}$ & $\begin{array}{c}\text { Mean No. of } \\
\text { Pustules } \\
\text { per Ave. Unit } \\
\text { Area of most Severely } \\
\text { Infected Leaf }\end{array}$ \\
\hline$A$ & 100 & sand & 47 & 5.1 & I I 6 \\
\hline$B$ & 100 & 委 sand & 53 & 5.1 & I 1.8 \\
\hline$E$ & I00 & $\begin{array}{c}\text { acid } \\
\text { phosphate }\end{array}$ & 93 & 5.2 & II .3 \\
\hline C & 100 & $\frac{1}{2}$ sand & 93 & 4.5 & 9.5 \\
\hline$D$ & 100 & $\mathrm{KCl}$ & 96 & 4.4 & 10.2 \\
\hline$F$ & 100 & $\mathrm{NaNO}_{3}$ & 359 & 3.1 & 7.6 \\
\hline
\end{tabular}

\section{Relation between Host Vigor and Pustule Size}

In all five of the soil-culture experiments there was evident a marked decrease in the size of the rust pustules on the host plants the growth rate of which was depressed. The lengths of 100 contiguous pustules on plants from groups $a$ and $c$ of experiment I; groups $a$ and $c$ of experiment II; groups $a$ and $d$ of experiment III; groups $A$ and $F$ of experiment IV; and groups $A$ and $F$ of experiment $\mathrm{V}$ were found to fall into the following classes: 
TABLE II

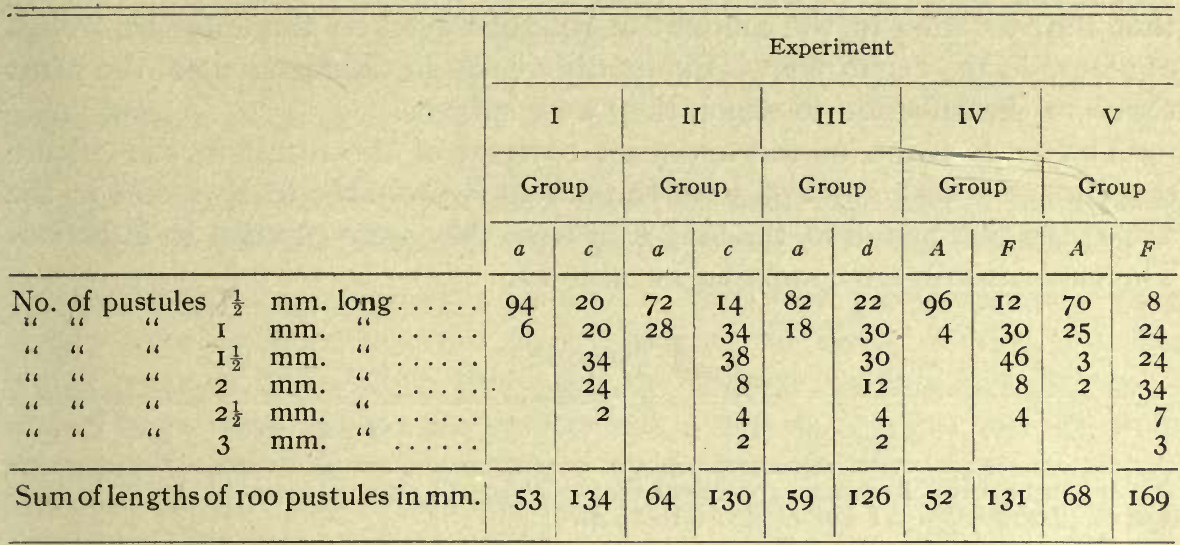

Figures 4 and 5 of Plate XII illustrate the relative size of the pustules on leaves of semi-starved and of vigorously growing plants.

Pustules attained a larger size on the more rapidly growing host plants, indicating that a more luxuriant host tissue means a more luxuriant parasitic mycelium.

\section{Discussion}

\section{Relation between Host Vigor and Incidence of Infection}

On their face the figures obtained in the soil-culture experiments indicate that in experiments I, II, III, and IV there occurred a decreased incidence of infection with depression in growth vigor of the host; but in experiment $\mathrm{V}$ the figures indicate quite as definitely precisely the opposite relationnamely, increased incidence of infection with depression in the growth rate of the host.

The dosage for all six groups of variables in soil-culture experiments IV and $\mathrm{V}$ was probably essentially the same. The plants were arranged in order of alphabetical designation of the groups: $A, B, C, D, E, F$. The possibility might be suggested that in experiment IV inoculation proceeded from the direction of $F$ and that the plants from $F$ to $A$ were subjected to progressively diminishing doses of inoculum; and, conversely, that in experiment $\mathrm{V}$ inoculation was from the direction of $A$ and that the plants from $A$ to $F$ received progressively diminishing doses of uredospores. This would make the amount of infection observed on the plants of the different groups a function of their positions relative to each other. But actually the amount of infection observed is correlated not with the position of the group but with its relative growth vigor as indicated by the mean dry weight of the plants. Thus, in both experiments IV and V, group $E$ exhibits an amount of infection not like group $F$, next to which it was placed, but like group $B$ which it resembles in vigor of growth. We may conclude that 
the dosage for the variables compared in any experiment was uniform and that the variation in the amount of rust observed on the different groups of plants in the experiment is due to differences in the reactions of the plant tissue to the infection to which they were subject.

The explanation of the apparent reversal of the result in soil-culture experiment $\mathrm{V}$ as compared with the others is probably to be found in the age of the plants and in the length of time they were exposed to infection. The experiments are compared in table $\mathrm{I} 2$.

TABLE 12

\begin{tabular}{|c|c|c|c|c|c|}
\hline Experiment & I & II & III & IV & $\mathrm{V}$ \\
\hline Age of plants at conclusion of experiment (days) & 49 & 49 & 49 & 47 & 45 \\
\hline 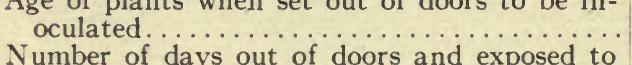 & 35 & 35 & 35 & $3 \mathrm{I}$ & 24 \\
\hline 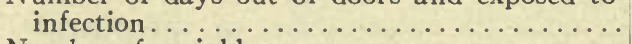 & I 5 & I5 & I5 & I6 & $2 \mathrm{I}$ \\
\hline 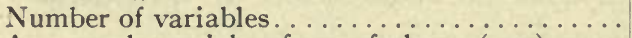 & 66 & 70 & 120 & 600 & 600 \\
\hline Average dry weight of top of plants (mg.) . . . . & 127 & 278 & 538 & 264 & 123 \\
\hline $\begin{array}{l}\text { Average infection (total leaf surface) } \ldots . . . . \\
\text { Average infection (most severely infected leaf).. }\end{array}$ & I. 8 & I.8 & 2.3 & .9 & 4.6 \\
\hline Average infection (most severely intected leat). & $5 \cdot 4$ & 4.7 & $5 \cdot 7$ & 3.0 & 10.4 \\
\hline
\end{tabular}

Experiment $\mathrm{V}$ differs from the other four experiments in that (I) when set out of doors to be inoculated the plants were from 7 to II days younger. Even at the conclusion of the experiment these plants had only half the dry weight of the plants of experiment IV and were evidently much less mature. (2) When the experiment was concluded the plants had been out of doors and subject to infection 6 days longer. If we allow an incubation period of Io days for the rust, then the rust present on the plants of experiment $\mathrm{V}$ at the conclusion of the experiment represents inoculation through a period of time twice as long as in the case of the other experiments. (3) The amount of rust on the plants at the conclusion of the experiment was several times greater in experiment $\mathrm{V}$ than in any of the other experiments.

The last-mentioned fact immediately brings into view an aspect of the method of experimentation used tending to limit the value of the pustule count as a criterion of the frequency of penetration and infection by the uredospore germ tube. It is probable that only in cases of very sparse infection is there a pustule for every focus of infection, and that only in cases of very sparse infection is the number of pustules counted an accurate index of the number of infections which have taken place. With abundance of infection there appears a tendency for the coalescence of foci of infection, for two or more mycelia the result of contiguous infections to coalesce and produce only one pustule; and this tendency would be highly accentuated on the more vigorously growing host plants where the parasite finds a favorable nidus and develops more luxuriantly. In experiment $\mathrm{V}$ the error introduced by the coalescence of mycelia may well have masked a 
higher incidence of infection in the vigorously growing plants of group $F$ and have converted it into an apparently lower susceptibility. It is noticeable that the pustules were larger in experiment $\mathrm{V}$ than in the other four experiments.

\section{Variation in the Incidence of Rust Infection with Variation in the Growth Vigor of the Host Plant, due to Constitutional or Racial Differences}

In soil-culture experiments IV and $V$, when the Ioo variables of each group were arranged in order of dry weight, the series divided into five equal parts of 20 variables each, and the average weights and degrees of infection of these sub-groups determined, a certain relation was apparent between the relative weight attained by a plant and the incidence of rust infection on it. The figures obtained in this analysis of the data are presented in table $\mathbf{I} 3$.

TABLE I3

Experiment IV

\begin{tabular}{|c|c|c|c|c|c|c|c|c|c|c|}
\hline \multirow{3}{*}{ Group } & \multicolumn{5}{|c|}{$\begin{array}{l}\text { Mean Dry Weight of Tops of } \\
\text { Plants in Mg. }\end{array}$} & \multicolumn{5}{|c|}{$\begin{array}{l}\text { Mean Infection per Unit Area of most } \\
\text { Severely Infected Leaf of Plant }\end{array}$} \\
\hline & \multicolumn{10}{|c|}{ Sub-groups } \\
\hline & First & Second & Third & Fourth & Fifth & First & Second & Third & Fourth & Fifth \\
\hline & 40 & 65 & IIO & I 48 & 239 & 2.3 & 2.4 & 1.8 & 2.0 & I. 6 \\
\hline & 99 & 129 & 148 & 172 & 231 & 2.8 & $2 . \mathrm{I}$ & 2.9 & 3.5 & 2.I \\
\hline$B$. & 99 & 140 & 179 & 231 & 345 & 2.3 & 2.9 & 2.5 & 2.1 & 1.8 \\
\hline$D$ & 90 & I 44 & I 82 & 231 & 363 & 3.6 & 3.0 & 2.5 & 3.9 & 2.9 \\
\hline & I 4I & 233 & 336 & 430 & 596 & 4.0 & 3.0 & 2.3 & 4.4 & 1.7 \\
\hline \multirow[t]{2}{*}{$F \ldots$} & 305 & $45^{\circ}$ & 555 & 653 & 812 & 4.7 & $5 \cdot 7$ & 5.2 & 3.8 & $3 \cdot 3$ \\
\hline & 129 & I93 & $25^{2}$ & 3II & $43 I$ & 3.3 & 3.2 & 2.9 & 3.3 & 2.2 \\
\hline
\end{tabular}

Experiment $V$

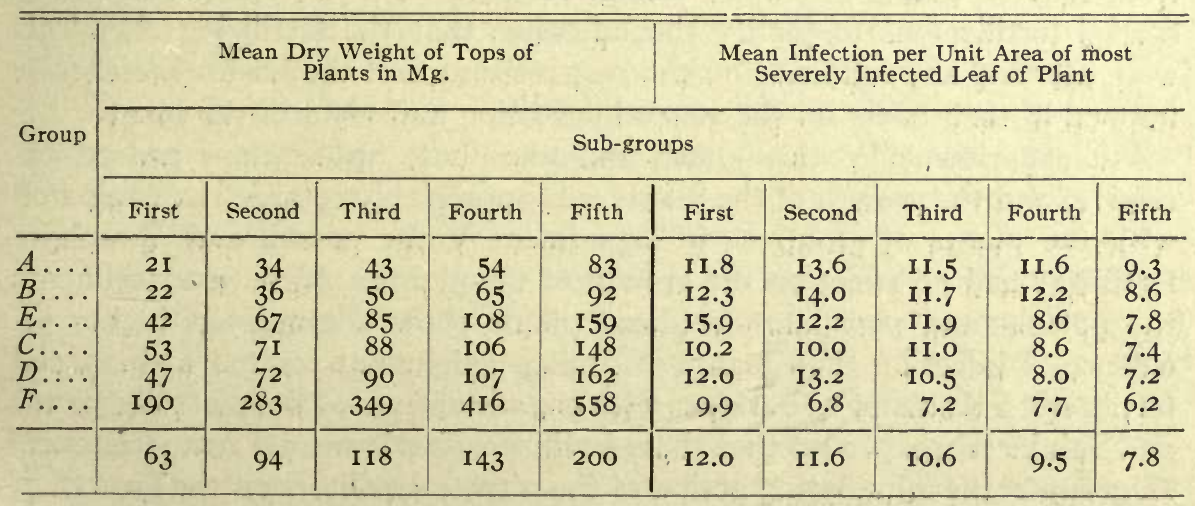

The figures show that there was considerable variation in the growth 
attained by plants receiving the same treatment, and that the larger plants were less susceptible to rust infection-increased resistance being particularly marked in the sub-group including the largest of the plants.

The seed employed was a commercial "Swedish Select" oats in which we should expect a mixture of strains as regards rate of growth, speed of maturity, and susceptibility to rust. In view of the uncertainty as to the varietal purity of the seed employed, the differences in incidence of rust infection on plants receiving the same treatment and showing differences in vigor of growth are probably indicative of constitutional differences in susceptibility to rust which may be correlated with similar constitutional differences in speed of growth; and so may be considered as not necessarily bearing on the main problem I am considering, which is concerned with the effect on rust susceptibility of externally induced variations in the vegetative vigor of the host. The establishment of an inverse relation between susceptibility to rust and speed of growth in oat varieties would lend, however, new significance to the practical injunction of the agronomists to plant early-maturing varieties of oats in order to escape loss from rust, indicating that selection of rapidly growing and early-maturing strains of oats automatically implies selection for rust resistance as well.

\section{The Possibility of a Direct Relation between Environmental Conditions and Rust Resistance}

Groups $D, E$, and $F$ in experiments IV and $\mathrm{V}$ were intended as tests for a possible direct effect on rust susceptibility of specific nutrient substancesthat is, an effect independent of variations in the health and vigor of the host plant. A potash fertilizer was applied to the plants of group $D$; a phosphate fertilizer to those of group $E$; and the plants of group $F$ were richly fed with a nitrogen salt.

The infection observed in these groups is in no instance so far different from that on plants of similar weight in the groups not treated with any special fertilizer as to justify the inference that the fertilizing chemicals were exerting any influence on the rust resistance of the host other than is implied in their effect on the general condition and vigor of the plant.

In experiment IV the potash and phosphate applications proved excessive, and the growth of the plants was appreciably retarded as compared with the plants of group $C$; in experiment $\mathrm{V}$ the potash and phosphate fertilizers had no effect on the growth of the plants. In both experiments the potash- and phosphate-fertilized plants show a somewhat higher incidence of infection than plants of similar weight not treated with special fertilizers; a tendency at variance with the statements of Bolley $(1889$, p. I 8) and Spinks (19I3, p. 247) that these fertilizers give increased rust resistance. In group $F$ the stimulating action of the nitrate fertilizers on the growth of the host was so marked that there can be no hesitation in referring the increased susceptibility observed to this effect rather than to any direct 
action of the chemical. This aspect of the soil-culture experiments may be considered as in agreement with the suggestion arrived at in the bibliographical review that it is questionable whether a direct relation between any environmental factor, either physical or chemical, of the nature of a nutrient or a stimulus, and susceptibility to rust, has been established in the case of the cereal grains.

\section{Vegetative Vigor of the Host as a Susceptibility- and Resistance-factor in Infectious Diseases}

Increased susceptibility with increased vigor of the host, in plant diseases, is not confined to the rusts. Marchal (1902) found that infection of lettuce by Bremia lactucae was favored by nitrogen and phosphates and retarded by an excess of potash. Jones (I905, p. 38) mentions that high fertilization; especially with nitrogenous manures, lowers the powers of the potato plant to resist blight and rot. McCue (I9I3, p. I8) observed that tomato plants treated with phosphatic fertilizers developed less leaf blight than control plants, while plants on nitrogen and potash plots which at the same time gave the highest yields, indicating greatest vigor of growth, were more heavily infected than the controls. Peltier (I9I8) has observed with the citrus canker, and Fromme and Murray (1919, p. 227) with the angular leaf spot of tobacco ("the development of the organism within the tobacco leaf is apparently dependent to a marked degree on those predisposing factors which promote a rapid, vigorous growth of the host"), that infection is heavier under conditions which favor the growth of the host. Thomas (I92I) obtained evidence of increased resistance to leaf spot (Septoria Apii) of celery plants the vitality of which was depressed as a result of infestation of the root system by nematodes; and of decreased resistance in plants richly fed. And Levine (I92I) has observed that crown gall on beets developed more rapidly and to larger size on roots grown in a highly manured soil.

While the claim that increased vigor of the host means greater susceptibility to an infection may appear somewhat anomalous from the point of view of current theories regarding the infectious diseases, observations such as form the subject of the present paper are readily understood when we consider the infectious diseases in the light of the larger class of biological phenomena of which they are an artificially selected group-namely, parasitism, commensalism, and symbiosis, the class of biological phenomena in which one organism lives within, and derives its sustenance from, the tissues of another living organism. In each of the four main groups of parasitic organisms - the bacteria, the protozoa, the worms, and the fungia series of intergradations are to be observed in the physiological interrelations of host and parasite, from the unceasing and violent struggle that continues until the destruction of one or other of the principals, to a relation of a more benign type characterized by great subordination and even tend- 
ency to usefulness on the part of the parasitic organism, and by the utmost tolerance on the part of the host. In many instances the nature of the reaction is not constant, but varies with the progress of the host-parasite relation. In this intergrading series of possible host-parasite relations, the inverse relation between host vigor and parasite virulence obtains only in the instances and phases where the reaction of the host to the parasite is one of active antagonism; here a more vigorous host means a host of greater physiological capacity to combat the progress of the invader. But when the relation between host and parasite is of a symbiotic type, a more vigorous host means a host in which more food is available for the development of the parasite. Because, of the general class of parasitological phenomena, the instances mainly in the field of pathological interest (the diseases ordinarily so called) are an artificially selected group in which relations of violent antagonism between host and invading organism are most prominently in evidence, thought in the field of pathology has developed with the physiological antagonism of host and parasite as its basal concept; and the theories of immunity extant are largely concerned with the nature of the antagonistic reactions.

In the group of the fungi the transition from violent and destructive parasitism to parasitism of the symbiotic type is accompanied by a transition from facultative to obligate parasitism, as if the physiological corollary of parasitism of the latter type is extreme specialization in food preferences. The series in the fungi grades from violent and destructive parasites like Botrytis, on the one hand, to, on the other hand, so benign an infestation as the seed fungus of Lolium temulentum (described by Freeman, 1903) in which the relation is so intimate and devoid of any untoward effect on the host, and the life history of the cohabiting organism is so parallel with that of the grass that its distinct individuality is almost open to question.

The mutualistic nature of the relation between host elements and fungus in rusts of the type of the cereal rusts is commented on by Tubeuf (1897, p. 91) who very aptly compares the mass of chlorophyll-bearing leaf cells infested with the rust mycelium to a lichen structure, especially to those lichens whose algae obtain water and inorganic materials direct, rather than through the fungous hyphae. Certainly, during the greater part of the relation, there is here no evidence of any deleterious effects on the host cells. While the contribution of the affected elements to the growth and fruiting economy of the host plant as a whole may be diminished, the infected protoplasts continue essentially unimpaired in structure and function. The parasite does not attack the living substance of the host protoplast, but confines itself to establishing such a relation with the latter that it shares the available food resources of the cell; and the rust haustorium is not an implement for mechanical disruption, but a structure more in the nature of the placenta of the mammalian foetus for establishing physiological communication with the food resources of the host. 
The data presented by Thomas (I92I) on the parallel relation between health of the host and infection in the case of the leaf blight of celery, and observations of similar occurrences in other diseases caused by non-obligate parasites like the late blight of the potato (Jones, 1905) and the crown gall of the beet (Levine, 192I) indicate that phases in which a symbiotic tendency comes to the fore may occur in diseases of a predominantly destructive type caused by facultative parasites, and suggests the generalization that the host-parasite relation in any given instance is not constant but may vary with the state and condition of the organisms and with the progress of the relation. It is important to recognize that there may occur mutualistic phases and stages in host-parasite relations of a violent and destructive type, just as there are destructive phases in parasitisms of a predominantly symbiotic tendency such as those of the mildews, the rusts, and the smuts.

\section{Conclusion}

The inquiry initiated by the occurrence in rust literature of statements of a relation between host vigor and susceptibility other than the inverse relation commonly conceived as existing between these variables can be considered as having brought forward evidence indicating that through most of the course of certain infectious diseases such as the rust diseases of the cereal grains, and in certain phases of other diseases like the leaf spot of celery and the crown gall of the beet, the vegetative vigor of the host and the virulence of the disease may be in direct relation. The demonstration of such a relation in diseases of large importance suggests, in turn, emendation of current pathological concepts of the relation between host vigor and pathogen activity into a form more in accord with our knowledge of parasitological phenomena in general. A more catholic point of view in pathologic thought, recognizing that, for longer or shorter phases in the course of a disease, the relation between host and parasite may be highly mutualistic, would be of material value as a working concept in the study of disease and in defining the practical problem of disease prevention and control.

The work presented in this paper was done in the Botanical Laboratory of Columbia University, under Professor R. A. Harper, to whom the writer is greatly indebted for pointing out the problem and for constant consultation and advice during the progress of the investigations. Acknowledgment is also made of indebtedness to Dr. Michael Levine for taking the photographs of the soil-culture experiments, and to Dr. H. E. Thomas for helpful advice in devising the method used in the dosage studies on the corn rust.

\section{LITERATURE CITED}

Adami, J. G. The principles of pathology. Vol. r. Philadelphia and New York, I9Io. Arthur, J. C. Problems in the study of plant rusts. Bull. Torr. Bot. Club 30: 1-I8. I903. Bailey, L. H. Cyclopedia of horticulture. New York, I9I4. 
Bailey, M. A. Puccinia malvacearum and the mycoplasm theory. Annals of Bot. 34: 73-100. 1920.

Biffen, R. A. Studies in the inheritance of disease resistance. Jour. Agr. Sci. 4: 42I-429. I9I2.

Bolley, H. L. Wheat rust. Ind. Agr. Exp. Sta. Bull. 26. I 889.

Burnham, S. H., and Latham, R. A. The flora of the town of Sothold, Long Island, and Gardiner's Island. Torreya 14: 201-225, 229-254. 1914.

Butler, E. J. Fungi and disease in plants. Calcutta, I9I8.

- and Hayman, J. M. Indian wheat rusts. Mem. Dept. Agr. India, Bot. Ser. I2: I-58. 1906.

Christman, A. H. Observations on the wintering of grain rusts. Trans. Wis. Acad. Sci., Arts, and Lett. 15: 98-107. 1905.

Clinton, G. P. Report of the Connecticut State Agricultural Experiment Station. I903. Eriksson, J., and Henning, E. Die Getreideroste. Stockholm, I896.

- and Hammarlund, C. Essais d'immunisation de la Rose tremière contre la maladie de la Rouille. Compt. Rend. Acad. Sci. Paris 158: 420-422. 1914.

Fischer, E. Die Uredineen der Schweiz. Bern, I904.

Freeman, E. M. The seed fungus of Lolium temulentum L., the darnel. Phil. Trans. Roy. Soc. Lond. B I96: I-27. Pls. I-3. 1903.

- and Johnson, E. C. The rusts of the grains in the United States. U. S. Dept. Agr. Bur. Plant Ind. Bull. 216. Pp. 87, 2 fig., I pl. I91 1.

Fromme, F. D. The culture of the cereal rusts in the greenhouse. Bull. Torrey Bot. Club 40: 50I-521. I9I3.

- and Murray, T. J. Angular leaf-spot of tobacco, an undescribed bacterial disease. Jour. Agr. Res. 16: 219-228. I919.

Galloway, B. T. Experiments in the treatment of rusts affecting wheat and other cereals. Jour. Mycol. 7: 195-226. I 893 .

Gassner, G. Die Teleutosporenbildung der Getreiderostpilze, und ihre Bedingungen. Zeitschr. Bot. 7: 65-120. I915.

Gibson, C. M. Notes on infection experiments with various Uredineae. New Phytol. 3: I 84-I9I. I904.

Giddings, N. J. Infection and immunity in apple rust. W. Va. Agr. Exp. Sta. Bull. I 70. I9I 8.

Grove, W. B. The British rust fungi. Cambridge, I9I3.

Hecke, L. Zur Frage der Überwinterung des Gelbrostes und das Zustandekommen von Rostjahren. Naturwiss. Zeitschr. Forst-u. Landw. I3: 213-220. 1915.

Humphrey, J. E. Report of the Massachusetts State Agricultural Experiment Station. I 891 .

Hungerford, C. W. Rust in seed wheat and its relation to seedling infection. Jour. Agr. Res. 19: 257-277. 1920.

Jellife, S. E. The flora of Long Island. Lancaster, Pa., I 889.

Johnson, E. G. Cardinal temperatures for the germination of uredospores of cereal rusts (Abstr.). Phytopath. 2: 47. 1912.

Jones, L. R. Disease resistance of potatoes. U. S. Dept. Agr. Bur. Plant Ind. Bull. 87. I 905 .

Jost, L. Lectures in plant physiology (Eng. transl. by Gibson). Oxford, 1907.

Kolmer, J. A. A practical text-book of infection, immunity, and specific therapy. Philadelphia, I917.

Laurent, E. Recherches expérimentales sur la mal des plantes. Ann. Inst. Past. I3: I-48. I 899.

Lauritzen, J. I. The relation of temperature and humidity to infection by certain fungi. Phytopath. 9: 7-36. I9I9.

Levine, M. Studies on plant cancers III. The nature of the soil as a determining factor 
in the health of the beet, Beta vulgaris, and its relation to the size and weight of the crown gall produced by inoculation with Bacterium tumefaciens. Amer. Jour. Bot. 8: $507-525$. I92I.

Little, W. C. Report on wheat mildew. Jour. Roy. Agr. Soc. Eng. 19: 634-693. 1883. McAlpine, D. The rusts of Australia. Melbourne, 1906.

McCue, C. A. Tomatoes for the canning factory. Del. Agr. Exp. Sta. Bull. ror ; I-86. I9I3.

Mains, E. B. The relation of some rusts to the physiology of their hosts. Amer. Jour. Bot. 4: 179-220. I9I 7.

Marchal, É. De l'immunization de la laitue contre le meunier. Compt. Rend. Acad. Sci. Paris 135: 1067, 1068. 1902.

Melhus, I. E. Culturing of parasitic fungi on the living host. Phytopath. 2: 197-203. I9I2.

Peacock, R. W. Rust in wheat and oats. Agr. Gaz. N. S. Wales 22: Ior3-Ior6. I9I I.

Peck, C. H. Report of the New York State Botanist. I87I.

Peltier, G. L. Susceptibility and resistance to citrus-canker of the wild relatives, citrus fruits, and hybrids of the genus Citrus. Jour. Agr. Res. 14: 337-358. 1918.

Plowright, C. B. The British Uredineae and Ustilagineae. London, I 889.

Sheldon, J. L. Preliminary studies on the rusts of the asparagus and carnation. Science, n. ser. 16: $235^{-237}$. 1902 .

- Infection and parasitism in Uredineae. (Typewritten thesis deposited in the library of the University of Nebraska.) Pp. I45. I903.

- The effect of different soils on the development of the carnation rust. Bot. Gaz. 40: 225-229. 1905 .

Smith, R. E. The water-relation of Puccinia asparagi. Bot. Gaz. 38: 19-43. I904.

- Asparagus and asparagus rust in California. Cal. Agr. Exp. Sta. Bull. I65. 1905.

Spinks, G. T. Factors affecting susceptibility to disease in plants. Part I. Jour. Agr. Sci. 5: 23I-247. I9I3.

Stakman, E. C. A study in cereal rusts; physiological races. Minn. Agr. Exp. Sta. Bull. 138: I-56. I9I4.

Jour. Agr. Res. I0: 429-496. I917.

- and Levine, M. N. Effect of certain ecological factors on the morphology of the urediniospores of Puccinia graminis. Jour. Agr. Res. 16: 43-77. I919.

Thaxter, R. Report of the Connecticut Agricultural Experiment Station, 1890.

Thomas, H. E. The relation of the health of the host and other factors to infection of Apium graveolens by Septoria apii. Bull. Torrey Bot. Club 48: I-29. I92I.

Tubeuf, K. F. von. Diseases of plants (Eng. transl. by Smith). London, 1897.

Voelcker, J. A. The Woburn pot-culture experiments, I9I0-I9II-I9I2. Jour. Roy. Agr. Soc. Eng. 73: 314-338. 1912.

Ward, H. M. On pure cultures of a Uredine, Puccinia dispersa (Erikss.). Proc. Roy. Soc. London 69: 45I-466. $1902(a)$.

- Experiments on the effect of mineral starvation on the parasitism of the Uredine fungus, Puccinia dispersa, on species of Bromus. Proc. Roy. Soc. London $7 \mathbf{I}$ : I38-I5I. I902 (b).

- On the relations between host and parasite in the bromes and their brown rust, Puccinia dispersa (Erikss.). Ann. Bot. 16: 233-315. 1902 (c).

- Recent researches on the parasitism of fungi. Ann. Bot. 19: I-55. 1905.

Wilson, J. K: Calcium hypochlorite as a seed sterilizer. Amer. Jour. Bot. 2: 420-428. I9I 5 .

Zavitz, C. A. Thickness of seeding in cereal grains. Ann. Rep. Canadian Seed Growers' Assoc. 9: 39-45. I9I3.

Zinsser, H. Infection and resistance. New York, I9I4. 


\section{DESCRIPTION OF PLATES}

\section{Plate XI}

FIG. I. View of one of the four series of pots of experiment $V$ of the soil-culture studies, illustrating the difference in vigor of growth between plants receiving different nutritive treatment.

FIG. 2. On the left, a pot containing 5 plants of group $A$ (grown in sand); and on the right a pot containing 5 plants of group $F$ (soil highly fertilized with $\mathrm{NaNO}_{3}$ ); experiment $\mathrm{V}$ of the soil-culture studies.

\section{Plate XII}

FIG. 3. Crown rust of oats. A rust mycelium exhibiting a very marked tendency towards teleutospore production. The first sorus produced by the mycelium (in the center) is a uredosorus. The others are teleutosori. Photographed with Zeiss $3.5 \mathrm{~cm}$. microplanar. $\times 24$.

FIG. 4. View of infected leaves of a semi-starved plant and of a richly fed plant of soil-culture experiment $\mathrm{V}$, showing larger size of pustules on more luxuriant host plant. Photographed with Zeiss microplanar. $\times 15$.

FIG. 5. Same as figure $4 . \quad \times 10$. 


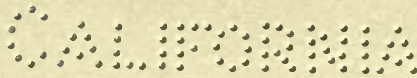

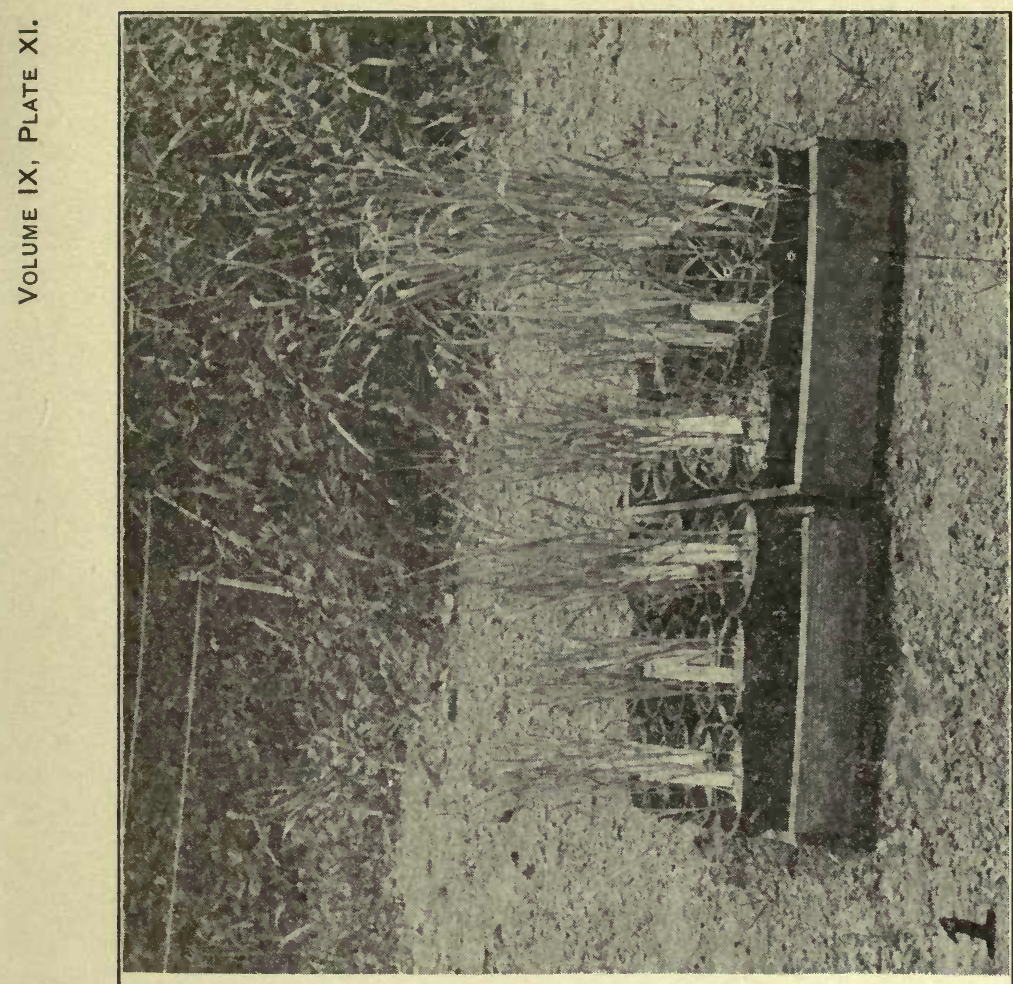

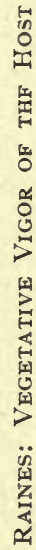




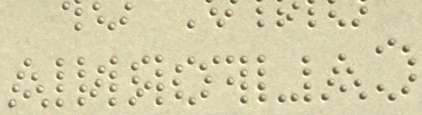



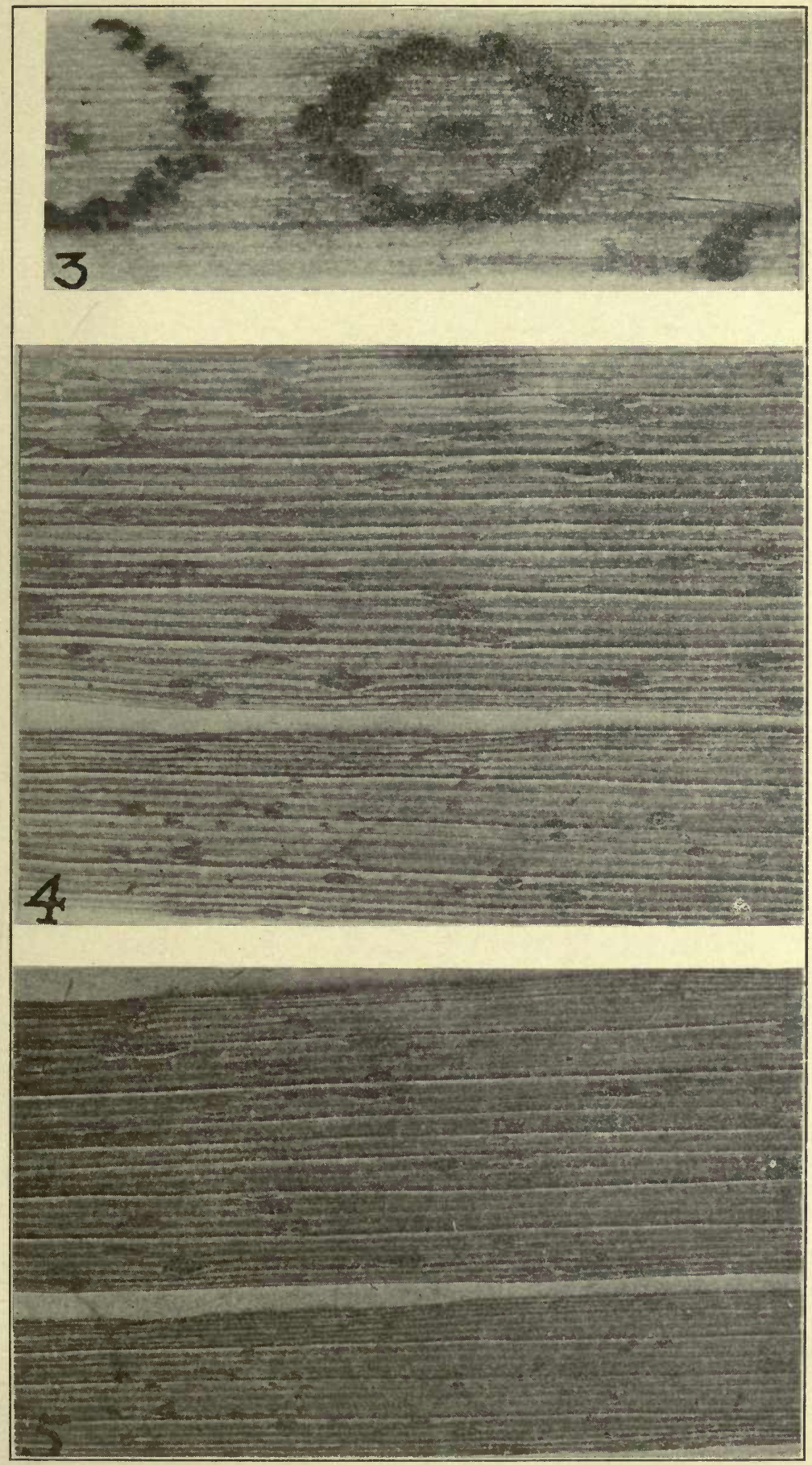
a) 


\section{VITA}

Morris Abel Raines. Born I894. Elementary and high school education in the public schools of New York City. Entered Columbia College in 1912. Received degree of Bachelor of Science "with high honors in botany and zoology," 1915; degree of Master of Arts in 1917. Pulitzer Scholar in Columbia University, I9I2-I9r6. Research Assistant in Botany in Columbia University, 1916-1917. Appointed Gottsberger Fellow in Columbia University for 1917-1918, but resigned to enter National Service. Flying Cadet, and later Lieutenant (airplane pilot, rated "Reserve Military Aviator") in the United States Army Air Service, I9I7-I9I8. Instructor in Botany in Columbia University Summer Session, 19I9. Gottsberger Fellow in Columbia University, 1919-1920. Instructor in botany in West Virginia University, I920-I922. 




\section{DAY USE}

RETURN TO DESK FROM WHICH BORROWED

AGRICULTURE LIBRARY

40 Giannini Hall - Tol. No. 642-4493

This book is due on the last date stamped below, or

Renewed books are subject to immediate recall.

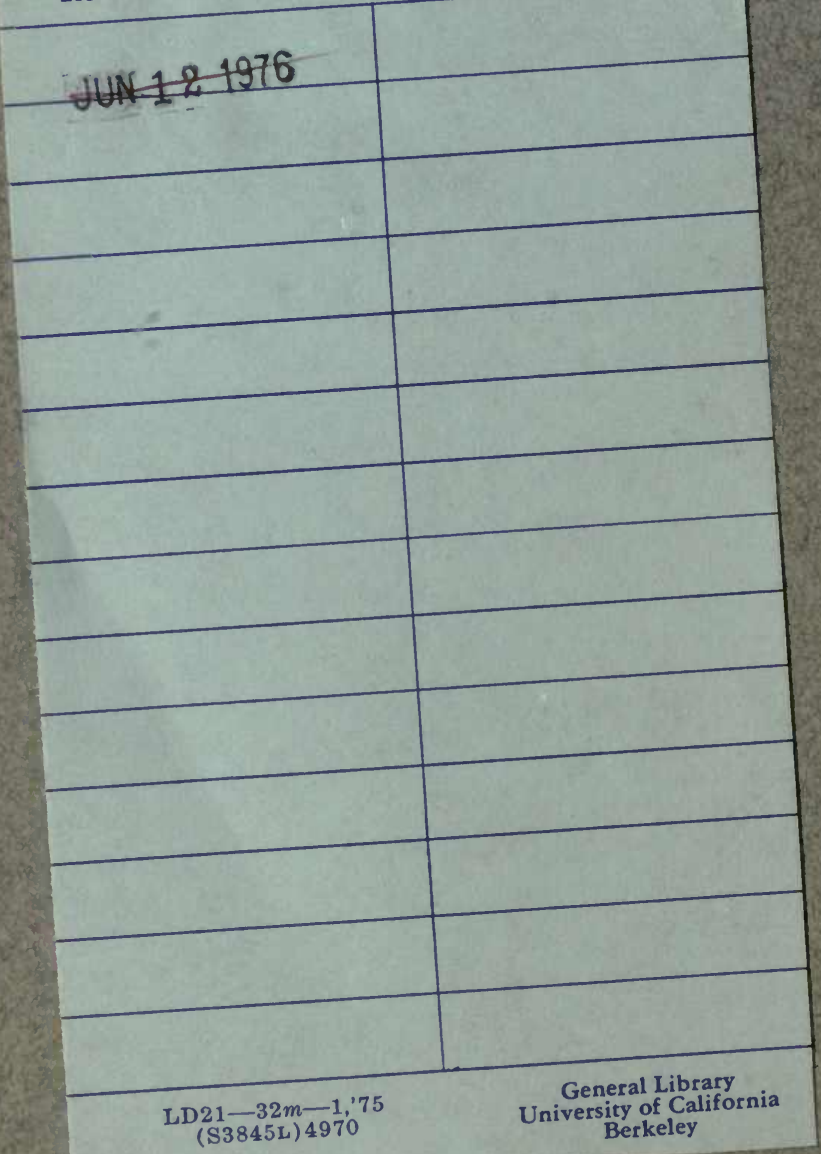


U.C. BERKEL

'DI'

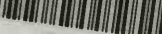

$\mathrm{CO}_{2} \mathrm{C}^{\circ}$

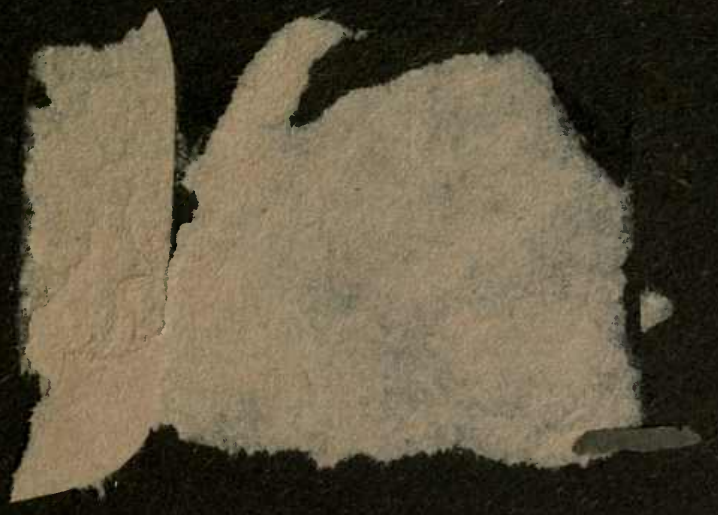


